\title{
Changes in animal performance and profitability of Holstein dairy operations after introduction of crossbreeding with Montbéliarde, Normande, and Scandinavian Red
}

\author{
C. Dezetter, ${ }^{*} \dagger \ddagger^{1}$ N. Bareille, ${ }^{*}$ D. Billon, ${ }^{*}$ C. Côrtes, $\dagger$ C. Lechartier, $\dagger$ and H. Seegers* \\ *BIOEPAR, INRA, Oniris, Université Bretagne Loire, La Chantrerie, 44307 Nantes, France \\ †Unité de Recherche sur les Systèmes d'Elevage (URSE), Ecole Supérieure d'Agricultures (ESA), Université Bretagne Loire, 55 rue Rabelais, \\ BP 30748, 49007 Angers Cedex, France \\ ‡PASS'SAS, 4 rue des Epicéas, 25640 Roulans, France
}

\section{ABSTRACT}

An individual-based mechanistic, stochastic, and dynamic simulation model was developed to assess economic effects resulting from changes in performance for milk yield and solid contents, reproduction, health, and replacement, induced by the introduction of crossbreeding in Holstein dairy operations. Three crossbreeding schemes, Holstein $\times$ Montbéliarde, Holstein $\times$ Montbéliarde $\times$ Normande, and Holstein $\times$ Montbéliarde $\times$ Scandinavian Red, were implemented in Holstein dairy operations and compared with Holstein pure breeding. Sires were selected based on their estimated breeding value for milk. Two initial operations were simulated according to the prevalence (average or high) of reproductive and health disorders in the lactating herd. Evolution of operations was simulated during $15 \mathrm{yr}$ under 2 alternative managerial goals (constant number of cows or constant volume of milk sold). After $15 \mathrm{yr}$, breed percentages reached equilibrium for the 2-breed but not for the 3-breed schemes. After 5 yr of simulation, all 3 crossbreeding schemes reduced average milk yield per cow-year compared with the pure Holstein scheme. Changes in other animal performance (milk solid contents, reproduction, udder health, and longevity) were always in favor of crossbreeding schemes. Under an objective of constant number of cows, margin over variable costs in average discounted value over the 15 yr of simulation was slightly increased by crossbreeding schemes, with an average prevalence of disorders up to $€ 32 /$ cow-year. In operations with a high prevalence of disorders, crossbreeding schemes increased the margin over variable costs up to €91/cow-year.

Received May 10, 2016.

Accepted May 15, 2017.

${ }^{1}$ Corresponding author: c.dezetter@groupe-esa.com
Under an objective of constant volume of milk sold, crossbreeding schemes improved margin over variable costs up to €10/1,000L (corresponding to around €96/ cow-year) for average prevalence of disorders, and up to $€ 13 / 1,000 \mathrm{~L}$ (corresponding to around $€ 117 /$ cow-year) for high prevalence of disorders. Under an objective of constant number of cows, an unfavorable pricing context (milk price vs. concentrates price) increased slightly crossbreeding positive effects on margin over variable costs. Under an objective of constant volume of milk, only very limited changes in differences of margins were found between the breeding schemes. Our results, obtained conditionally to the parameterization values used here, suggest that dairy crossbreeding should be considered as a relevant option for Holstein dairy operations with a production level until 9,000 kg/ cow-year in France, and possibly in other countries.

Key words: dairy crossbreeding, animal performance, profitability, modeling

\section{INTRODUCTION}

Efficient control of fertility and health is currently acknowledged as a main target to increase profitability of dairy operations, due to the economic impact of poor fertility or poor health performance (Fourichon et al., 2001; De Vries, 2006; Inchaisri et al., 2010). Another target to increase profitability is obtaining better milk prices by increasing quality, especially milk solid contents. For dairy operations relying on the Holstein herd, these 2 targets often appear particularly relevant.

Within breed, genetic improvement of these traits is possible (Taylor et al., 2016); for example, reproductive and health genetic merit of Holstein cows has slightly increased in the past $10 \mathrm{yr}$ (Berry et al., 2014). Nevertheless, given the superiority of milk quality, reproduction, and health traits of several other dairy breeds, dairy crossbreeding might be an alternative option to 
pure breeding to improve these traits faster. Indeed, differences up to -0.33 of somatic cell log score and up to 2.7 and $1.1 \mathrm{~g} / \mathrm{kg}$ of fat and protein contents were found in favor of Montbéliarde, Normande, and Norwegian Red breeds in comparison with the Holstein breed (Walsh et al., 2008; Dezetter et al., 2015). These breeds were estimated to be superior to the Holstein breed for pregnancy rate (10 to 13 points) by Walsh et al. (2008) and Dezetter et al. (2015). When crossbreeding Holstein with such breeds, the positive additive effects on these traits, resulting from breed differences, could be amplified by an expected heterosis effect of around 0 to 6,0 to 8 , and 7 to $10 \%$ of the parental mean for milk contents, SCC, and fertility, respectively (Dechow et al., 2007; Sørensen et al., 2008; Dezetter et al., 2015). However, Montbéliarde and Normande were still found genetically lower for milk yield by about 700 to 2,500 $\mathrm{kg}$ for 305-d mature-equivalent yield when compared with Holstein breed (Penasa et al., 2010; Dezetter et al., 2015). When crossbreeding Holstein with such breeds, this potential negative effect could lead to a possible reduction in milk yield of crossbreds that might be limited by an expected heterosis effect of around 3 to $5 \%$ (Dechow et al., 2007; Sørensen et al., 2008; Dezetter et al., 2015).

Despite its potential advantages, dairy crossbreeding is still scarcely implemented in most western countries. Countries with a dominancy of purebreds have recently been the subject of research dairy crossbreeding (Buckley et al., 2014). Very few studies have compared profitability of crossbred cows with Holstein cows. LopezVillalobos et al. (2000) and Heins et al. (2012) reported higher benefits for crossbreds (up to NZ $\$ 195$ for net income per hectare and up to $\$ 0.22$ for lifetime profit per day, respectively). No previous studies focused on profitability during the long transition phase that is needed before reaching equilibrium in breed percentages in the herd. To make the decision to implement dairy crossbreeding, farmers need relevant information on the costs and benefits expected for their specific dairy operation, especially during this transition phase. This will allow them to compare these figures with those expected within breed genetic improvement.

Therefore, the current study aimed to assess the effects of introducing crossbreeding in Holstein herds on animal performance, profitability, and workload using a dynamic simulation model. We hypothesized that changes might depend upon different scenarios for (1) the dairy breeds used and the crossbreeding scheme implemented, (2) the initial average milk yield per cow and initial reproductive and health conditions of the herd, and (3) the relative prices of milk sold and concentrates purchased.

\section{MATERIALS AND METHODS}

\section{Study Design Overview and Scenarios Tested}

Initial Dairy Operations and Associated Herd Reproductive and Health Performance. Two initial dairy operations with similar distribution of genetic merit for 120 pure Holstein cows were modeled (Table 1 ). The first was set up for an average prevalence of reproductive and health disorders and a milk yield of $9,000 \mathrm{~L} /$ cow-year. The second was set up for a high prevalence of reproductive and health disorders and a milk yield of $8,500 \mathrm{~L} /$ cow-year.

Breeding Schemes. Four breeding schemes were set up. First, (1) a pure Holstein breeding scheme (HO) was simulated such that all $\mathrm{HO}$ cows were mated to HO bulls; then, (2) a 2-breed scheme with Holstein and Montbéliarde $(\mathbf{H O} \times \mathbf{M O})$ was simulated as first AI occurring in yr 1 of simulation, with all $\mathrm{HO}$ females mated to MO bulls to produce first generation (F1) $\mathrm{HO} \times \mathrm{MO}$ offspring. Half of the $\mathrm{F} 1$ females were mated to $\mathrm{HO}$ bulls to produce $3 / 4 \mathrm{HO} 1 / 4 \mathrm{MO}$ offspring, and the other half were mated to MO bulls to produce $1 / 4$ HO 3/4 MO offspring. These crossbred females were mated to bulls from the other breed than cows' sire, and so on for the next generations of crossbred females. (3) A 3-breed scheme with Holstein, Montbéliarde, and Normande $(\mathbf{H O} \times \mathbf{M O} \times \mathbf{N O})$ and $(4)$ a 3 -breed scheme with Holstein, Montbéliarde, and Scandinavian Red $(\mathbf{H O} \times \mathbf{M O} \times \mathbf{S R})$ were also simulated. First AI occurred in yr 1 of simulation, with all $\mathrm{HO}$ cows mated to $\mathrm{MO}$ bulls to produce $\mathrm{F} 1 \mathrm{HO} \times \mathrm{MO}$ offspring. Then, F1 females were mated to NO or SR bulls to produce $1 / 4 \mathrm{HO} 1 / 4 \mathrm{MO} 1 / 2 \mathrm{NO}$ or SR offspring, which were mated to $\mathrm{HO}$ bulls to produce $5 / 8 \mathrm{HO} 1 / 8 \mathrm{MO} 1 / 4 \mathrm{NO}$ or SR, and so on.

Cow-Herd Size and Herd Milk Production Management of Dairy Operation. First, we simulated a management objective of keeping a constant number of cows per year in the herd over the whole simulation period, assuming that the housing capacity was a limiting factor. Second, we simulated a management objective of keeping a constant volume of milk sold per year, assuming a signed contract with a dairy company (Schlecht and Spiller, 2012).

\section{Time Horizon and Number of Replications in Simulation Runs}

A time horizon of 15 yr was chosen for 2 reasons: (1) the transitory period from pure Holstein herd to stabilized regimen in genotypic composition of the herd is quite long, and (2) farmers do not take decisions beyond $15 \mathrm{yr}$. The number of replications was tested to 
stabilize the standard error for the margin over variable costs between replications. The number of replications for this study was fixed to 250 .

\section{Simulation Model and Parameters}

Main Characteristics of the Model. Herd in the simulated operations was considered as a managed group of cows and heifers, with explicit representation of all demographic events through individual-based mechanistic, stochastic, and dynamic (time step of one day) simulation. Herd-level animal performance and profitability of operation were computed from individual results. Each daily animal performance (milk yield, milk fat and protein contents, and reproductive and health events) was modeled from the individual producing ability, the parity, and the most influential management decisions and feed distribution. Main interactions regarding milk production, reproduction, and health occurring during a lactation-reproduction cycle were integrated. Coding was done using Visual Basic (1998, Microsoft Corp., Redmond, WA).

Modeling Producing Abilities. Producing abilities $\left(\mathrm{PA}_{\mathrm{ij}}\right)$ of female i for milk yield in kilograms (MY), milk fat content in grams per kilogram (FC), milk pro- tein content in grams per kilogram $(\mathbf{P C})$, fertilization (FE; defined as success after an AI and including early embryonic death), and mastitis susceptibility (MAS), were computed at conception or at purchase of a female, and remained the same through all the female life, as

$$
\mathrm{PA}_{\mathrm{ij}}=\mathrm{PA}_{\mathrm{refj}}+\mathrm{TBV}_{\mathrm{ij}}+\mathrm{h}_{\mathrm{i}} \mathrm{H}_{\mathrm{j}}+\mathrm{Ep}_{\mathrm{ij}}+\mathrm{e}_{\mathrm{ij}}
$$

where $\mathrm{PA}_{\text {refj }}=$ baseline value for producing ability for trait $\mathrm{j}$, which was fixed and applied to every female born over the whole simulation period; $\mathrm{TBV}_{\mathrm{ij}}=$ true breeding value (TBV) of female $i$ for trait $j ; h_{i}=$ coefficient on heterosis expressed by female i calculated as in Dezetter et al. (2015); $h_{i}=1-\sum_{k=1}^{3} s_{i k} d_{i k}$ (where $s_{i k}$ $=$ proportion of sire genes from breed $\mathrm{k}$ for female $\mathrm{i} ; \mathrm{d}_{\mathrm{ik}}$ $=$ proportion of dam genes from breed $\mathrm{k}$ for female $\mathrm{i}$ ); $\mathrm{H}_{\mathrm{j}}=$ heterosis effect for trait $\mathrm{j} ; \mathrm{Ep}_{\mathrm{ij}}=$ permanent environmental effect of female $\mathrm{i}$ for trait $\mathrm{j}$; and $\mathrm{e}_{\mathrm{ij}}=$ residual effect of female i for trait j. Parameters for $\mathrm{PA}_{\text {ref }}$ and $\mathrm{H}$ are given in Table 2. How correlations between traits for permanent environment and residual effects were taken into account is detailed in Supplemental Materials (https://doi.org/10.3168/jds.2016-11436).

Computation of $\boldsymbol{T B V}$. Sires of simulated females were stochastically triggered in a pool composed of 10

Table 1. Main characteristics of Holstein herds for initial operations according to level in prevalence of reproductive and health disorders

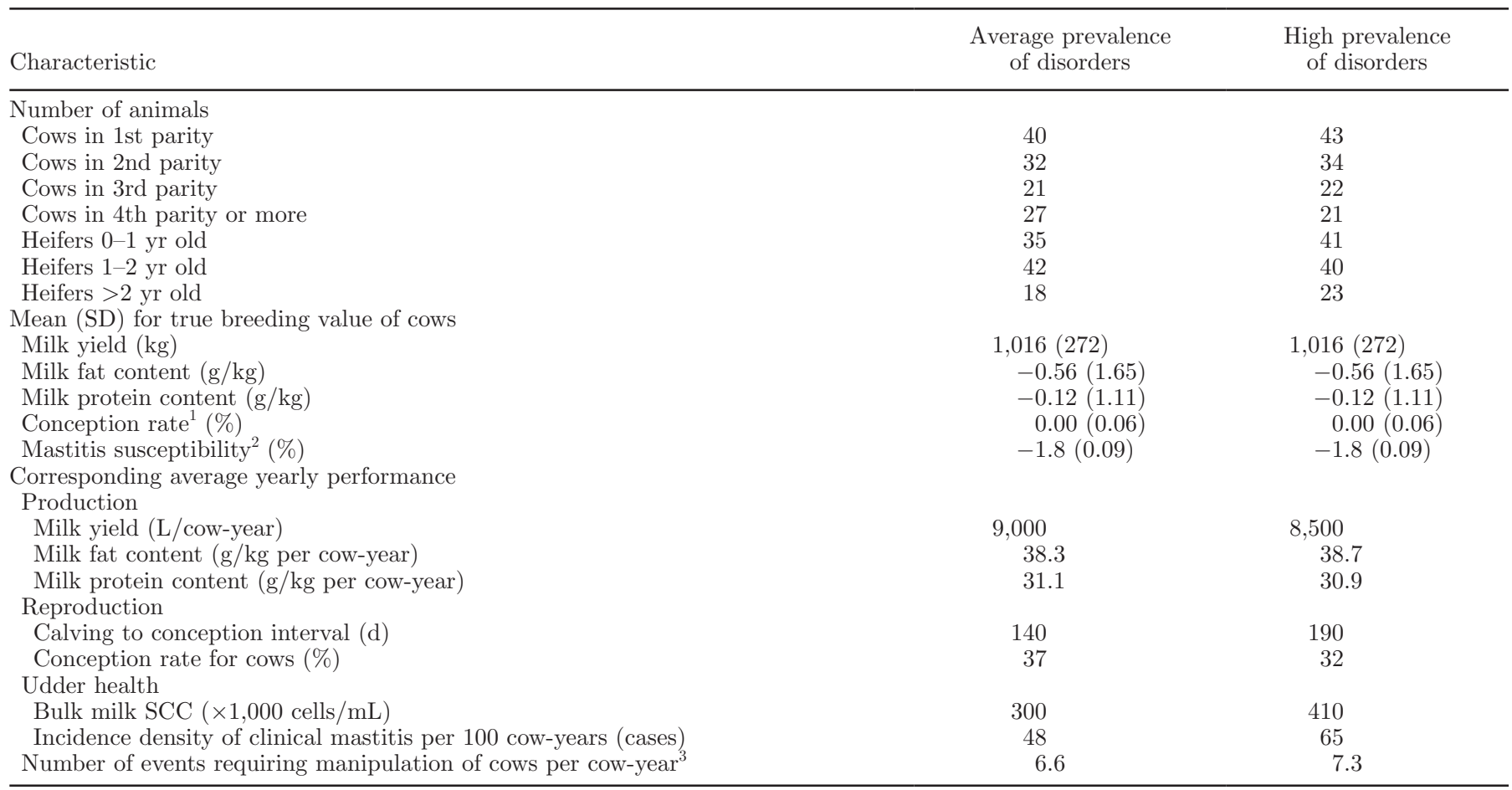

${ }^{1}$ Conception was defined as fertilization not followed by early embryonic death.

${ }^{2}$ Mastitis susceptibility was defined as proportion of lactations with at least one clinical case observed from calving to 150 DIM (0/1).

${ }^{3}$ The number of events requiring manipulation of cows is the sum of all treatments regarding udder health, treatments regarding other health disorders, hormonal treatments regarding reproductive disorders, and number of AI and calving events. 
bulls for each breed. To create those pools, we selected the 10 top sires according to their EBV for milk yield. We extracted their EBV for MY, FC, PC, FE, and MAS from the February 2014 French genetic evaluation (idele.fr/services/outils/index-officiels-des-taureaux .html; accessed Mar. 5, 2014) for the Holstein, Montbéliarde, and Normande breeds and the Nordic cattle genetic evaluation (https://nordic.mloy.fi/navbull; accessed Mar. 5, 2014) for the Scandinavian Red breed. Over the whole simulation period, analogous selected samples of bulls were used every year with an annual genetic gain applied on EBV as

$$
\mathrm{EBV}_{\text {skjn }}=\mathrm{EBV}_{\mathrm{skj} 0}+(\mathrm{n}-1) \text { genetic gain }_{\mathrm{kj}} \text {, }
$$

where $\mathrm{EBV}_{\text {skjn }}=\mathrm{EBV}$ of sire $\mathrm{s}$ from breed $\mathrm{k}$ for trait $\mathrm{j}$ computed at year $\mathrm{n}$ of simulation; $\mathrm{EBV}_{\text {skj } 0}=\mathrm{EBV}$ of sire $\mathrm{s}$ from breed $\mathrm{k}$ for trait $\mathrm{j}$ extracted from national genetic evaluation at the beginning of the simulation; and genetic gain ${ }_{\mathrm{kj}}=$ annual genetic gain applied for trait $\mathrm{j}$ and breed k. Parameters for EBV and genetic gain are given in Table 3.

The associated true breeding value for trait $\mathrm{j}$ for sire $\mathrm{s}$ from breed $\mathrm{k}\left(\mathrm{TBV}_{\mathrm{skjn}}\right)$ was stochastically triggered every year $\mathrm{n}$ of the simulation from the normal distribution with mean $\mu$ and standard deviation $\sigma$ as

$$
\begin{aligned}
\mathrm{TBV}_{\text {skjn }} & \sim N\left[\begin{array}{l}
\mu=\mathrm{EBV}_{\text {skjn }}, \\
\sigma=\sqrt{\left(1-\text { accuracy }_{\mathrm{j}}\right) \times \text { Genetic variance }_{\mathrm{jk}}}
\end{array}\right] \\
& +\Delta \mathrm{TBV}_{\mathrm{jk}},
\end{aligned}
$$

where $\mathrm{EBV}_{\text {skjn }}=\mathrm{EBV}$ of sire $\mathrm{s}$ from breed $\mathrm{k}$ for trait $\mathrm{j}$

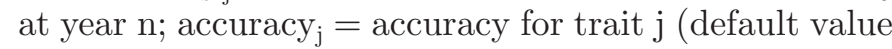
$=0.70)$; Genetic variance ${ }_{\mathrm{jk}}=$ genetic variance for trait $\mathrm{j}$ and breed k. As EBV of sires from different breeds than Holstein were not from the same genetic base, we applied breed difference $\left(\Delta \mathrm{TBV}_{\mathrm{jk}}\right)$ between the breed $\mathrm{k}$ and the Holstein breed for trait j. Parameters for breed differences and genetic variances are given in Table 2 and Table 3, respectively.

The model determined TBV for MY, FC, PC, conception rate, and MAS of females conceived during year $\mathrm{n}$ of simulation as

$$
\mathrm{TBV}_{\mathrm{ij}}=1 / 2\left(\mathrm{TBV}_{\mathrm{dj}}+\mathrm{TBV}_{\mathrm{skjn}}\right)+\mathrm{MS}_{\mathrm{ij}},
$$

where $\mathrm{TBV}_{\mathrm{ij}}=\mathrm{TBV}$ of female i for trait $\mathrm{j}$; $\mathrm{TBV}_{\mathrm{dj}}=$ TBV of the female's dam $d$ for trait $j$, which was computed following the same pattern than $\mathrm{TBV}_{\mathrm{ij}} ; \mathrm{TBV}_{\mathrm{sjn}}=$ TBV of female's sire s of breed $k$ for trait $j$ at the moment of the conception in year $\mathrm{n}$; and $\mathrm{MS}_{\mathrm{ij}}=$ Mendelian sampling effect for female $i$ and trait $j$, which was triggered stochastically from the normal distribution $N(\mu=0, \sigma=\sqrt{1 / 2 \times \text { genetic variance of trait } \mathrm{j}})$. Correlations between traits for genetic effect were not taken into account in this first case. We assumed that, because we used TBV from real bulls, these correlations were already taken into account.

The model determined the TBV of purchased females from normally distributed variations using Cholesky decomposition to take into account genetic correlations between traits. Modeling TBV of purchased females is detailed in Supplemental Materials (https://doi.org/10 .3168/jds.2016-11436).

Computation of Phenotypes. Each day of simulation, as well as for each female, reproductive and health statuses were updated, a feed ration was distributed, and, for lactating cows, milk production was attributed, including a possible effect of feeding or health disorders. We modeled all events occurring during a reproductive cycle (Appendix A). In summary, the probability of fertilization was determined by individual producing ability for conception rate and multiplicative factors for parity, rank of current ovulation since calving, nor-

\begin{tabular}{|c|c|c|c|c|c|}
\hline \multirow[b]{2}{*}{ Trait $^{2}$} & \multirow[b]{2}{*}{$\mathrm{PA}_{\text {ref }}$} & & \multirow[b]{2}{*}{$\mathrm{H}$} \\
\hline & & $\mathrm{MO}$ & NO & SR & \\
\hline Milk fat content $(\mathrm{g} / \mathrm{kg})$ & 39.75 & 0.30 & 3.25 & 2.45 & 0.15 \\
\hline Milk protein content $(\mathrm{g} / \mathrm{kg})$ & 32.05 & 0.30 & 1.45 & 0.60 & 0.00 \\
\hline Mastitis susceptibility (\%) & 24 & -4 & 0 & -4 & 0 \\
\hline
\end{tabular}

Table 2. Parameters for baseline values of producing abilities $\left(\mathrm{PA}_{\text {ref }}\right)$, breed differences between Montbéliarde (MO), Normande (NO), or Scandinavian Red (SR) and Holstein (HO), and heterosis effects $(\mathrm{H})^{1}$

Breed difference from $\mathrm{HO}$

${ }^{1}$ Baseline values for producing abilities were set up by the authors; breed differences and heterosis effects were those obtained in Dezetter et al. (2015) for milk yield, milk fat, and protein contents and conception rate. Values for mastitis susceptibility were computed from Rupp and Boichard (2003) and personal communication by D. Boichard (Institut National de la Recherche Agronomique, Jouy en Josas, France). Breed differences between Holstein and Scandinavian breed were provided by Jönsson (2015).

${ }^{2}$ Conception was defined as fertilization not followed by early embryonic death; mastitis susceptibility was defined as proportion of lactations with at least 1 clinical case observed from calving to 150 DIM $(0 / 1)$. 
mality of the current estrus cycle, occurrence of health disorders, and daily milk yield. For Holstein cows or heifers bred with Montbéliarde sires, the probability of fertilization was multiplied by 1.20 .

Modeling IMI occurrence is explained in Appendix B. In brief, for lactating cows, the probability of IMI occurrence was dependent on individual producing ability for MAS and multiplicative factors for parity, occurrence of a previous IMI during the same lactation, lactation stage, daily milk yield, and herd environmental factors.

Details on feed distribution are displayed in Supplemental Materials (https://doi.org/10.3168/jds.2016 -11436). In brief, daily amounts of roughage and concentrates were distributed to each animal, taking into account its reproductive status, DIM, actual yield, and following fixed distribution plans.

Simulation processes for final milk yield and milk solid contents are given in Appendix C. Daily milk yield, daily fat content, and daily protein content were calculated based partially on Wood (1967) and Coulon et al. (1995).

Simulation Processes for Culling and CowHerd Size Management. Heifers that were not pregnant after 3 services were culled. Every 15 d, if necessary, cows could be culled or freshening heifers near calving could be purchased. The number of culled cows or purchased heifers was determined to maintain constant the number of cows per year or the volume of milk sold per year (Supplemental Materials; https:// doi.org/10.3168/jds.2016-11436). To mimic in a certain way the real culling decisions of farmers, a culling candidacy score was computed according to age, milk yield, reproductive status, and health status of each cow. Details on modeling candidacy score are given in Supplemental Materials, as are details on simulation processes regarding replacement rearing.

\section{Simulation Outcomes of Effects of Introducing Crossbreeding in Holstein Herds}

Genotypic Composition of the Cow Herd. Numbers of Holstein, F1, second generation crossbred (G2), third generation crossbred (G3), and fourth and followed generation crossbred (G4) cows were computed at the end of each simulated year. Breed percentages in the herd were also computed at the end of each simulated year.

Animal Performance. Performance for 305-d milk, fat, and protein yield and calving to conception interval obtained from the 250 replications were averaged per genotypes (i.e., pure Holstein, $\mathrm{HO} \times \mathrm{MO}$, and $\mathrm{HO} \times$ $\mathrm{MO} \times \mathrm{NO}$ and $\mathrm{HO} \times \mathrm{MO} \times \mathrm{SR})$. As an annual genetic gain was applied, only performance obtained the same year for cows in the same parity could be compared. 
Hence, we compared F1 crossbred cows from the HO $\times$ MO scheme with pure Holstein cows from the HO scheme in parity 1 to 4 at yr 7 and 8 of the simulation. We also compared $\mathrm{HO} \times \mathrm{MO} \times \mathrm{NO}$ and $\mathrm{HO} \times \mathrm{MO} \times$ SR second generations of crossbred cows and pure Holstein cows from HO scheme in parity 1 to 4 at yr 11 and 12. Years 7 and 8 were chosen because F1 crossbreds were predominant in the herd at that time, whereas yr 11 and 12 were chosen because second generation of crossbreds were predominant.

Yearly averages over the 15 yr of simulation were calculated for (1) milk yield per cow-year and milk fat and protein contents; (2) conception rate, calving to conception interval, and number of clinical mastitis cases per 100 cow-years; and (3) number of culled cows per 100 cow-years. Results in pure Holstein operations were considered as the reference. Results in operations with crossbreeding were expressed as a difference from the reference.

Economic Performance and Workload. Revenues from milk sales were calculated each month. Milk pricing system was based on milk composition and SCC criteria. Revenues from culled cows, heifers, and calves and animal purchasing costs were computed according to their genotype. Variable costs were computed based on unitary costs per event or per animal. Computation of revenues and variable costs are detailed in Supplemental Materials (https://doi.org/10.3168/jds.2016 -11436). Parameters for milk pricing, feed costs, and values of culled animals are given in Appendix D Table D1. When a deviation of more than $4 \%$ of distributed roughage was found between operation with Holstein and operations with crossbreeding, feeding costs were adjusted by $€ 30$ per tonne of distributed roughage variation. Finally, margin over variable costs was computed as

$$
\begin{aligned}
& \text { Margin over variable costs }= \\
& \sum_{\mathrm{n}=1}^{15}\left[\left(\text { Revenues }_{\mathrm{n}}-\text { Variable costs }_{\mathrm{n}}\right) \times(1+0.03)^{-\mathrm{n}}\right],
\end{aligned}
$$

where revenues and variable costs of year $n$ were computed as defined previously. Discounting at 3\% per year was applied to compute average cumulated discounted margin over variable costs over 15 yr. Therefore, margin over variables costs was cumulated over 3 periods, the short-term period (yr 1 to 4), the mid-term period (yr 5 to 9), and the long-term period (yr 10 to 15). Cumulated margin over variable costs was also computed over the whole period (yr 1 to 15). In this study, we took the option to maintain the general structure of the farm constant, assuming that all fixed costs remained unchanged. Fixed costs were related to manpower, housing and milking facilities, pasture management, and roughage production or purchase. With these options, changes in such a margin over variable costs are directly changes in profit.

Workload might be an important nonmonetary criterion for farmers. Variation in number of cows under an objective of constant volume of milk sold was computed. The cumulated number of events requiring manipulation or surveillance of cows averaged per cow-year was computed as an occurrence counter for AI, treatments for mastitis or infertility, and calving events.

\section{Sensitivity of Margin Over Variable Costs to Price Context}

For the reference scenario, milk and animals prices and concentrates costs were computed with 2014 values from France. Prices and costs are given in Appendix D. Two relative price contexts were studied compared with this reference price context: (1) selling prices were reduced by $20 \%$ and the concentrates costs increased by $20 \%$, and (2) selling prices were increased by $20 \%$ and the concentrates costs reduced by $20 \%$.

\section{RESULTS}

\section{Average Genotypic Composition of the Cow Herd per Year}

Genotypic composition of the herds slowly evolved, with several generations of crossbreds being present at the same time in the herd (Figure 1). We identified 3 periods: (1) from yr 1 to 5, Holstein cows were still the most numbered and the first F1 cows entered during yr 3 ; (2) from yr 5 to $10, \mathrm{~F} 1 \mathrm{HO} \times \mathrm{MO}$ cows were in majority, slowly replaced by further generations of crossbred cows; (3) after yr 10, all Holstein cows had disappeared. After $15 \mathrm{yr}$, for the $\mathrm{HO} \times \mathrm{MO}$ scheme, average breed compositions in the herd were $50 \% \mathrm{HO}$ and $50 \% \mathrm{MO}$, showing that equilibrium in breed percentages was reached. This was not the case for the 3 -breed schemes. Indeed, breed percentages were, on average, $43 \% \mathrm{HO}, 29 \% \mathrm{MO}$ and $28 \% \mathrm{NO}$ or SR for $\mathrm{HO} \times \mathrm{MO} \times$ $\mathrm{NO}$ and $\mathrm{HO} \times \mathrm{MO} \times \mathrm{SR}$ schemes, respectively,

\section{Animal Performance per Crossbred Type}

Table 4 and Table 5 show results for milk and reproductive performance of $\mathrm{HO}$ cows and $\mathrm{F} 1$ cows during yr 7 and 8 of simulations and of $\mathrm{HO}$ cows and $\mathrm{HO} \times$ $\mathrm{MO} \times \mathrm{NO}$ and $\mathrm{HO} \times \mathrm{MO} \times \mathrm{SR}$ crossbreds during $\mathrm{yr}$ 11 and 12, respectively. Holstein cows were superior $(P<0.01)$ to all of the crossbred types for milk and 
protein yields. For fat yield, $\mathrm{HO}$ cows were superior to $\mathrm{F} 1$ and $\mathrm{HO} \times \mathrm{MO} \times \mathrm{NO}$ crossbreds, but not to $\mathrm{HO}$ $\times \mathrm{MO} \times \mathrm{SR}$ crossbreds. Holstein cows needed more $(P<0.01)$ days from calving to conception than all crossbred types.

\section{Animal Performance in Operations}

As management objectives (number of cows or volume of milk sold) did not affect individual animal performance, only results for a constant number of cows are detailed below.

Average Milk Production per Cow-Year. From yr 1 to $4, \mathrm{HO} \times \mathrm{MO}, \mathrm{HO} \times \mathrm{MO} \times \mathrm{NO}$, and $\mathrm{HO}$ $\times \mathrm{MO} \times \mathrm{SR}$ schemes provided similar milk per cowyear and fat and protein contents (Figure 2); they also provided higher milk per cow-year than $\mathrm{HO}$ in both types of operations. The $\mathrm{HO} \times \mathrm{MO}, \mathrm{HO} \times \mathrm{MO} \times \mathrm{NO}$, and $\mathrm{HO} \times \mathrm{MO} \times \mathrm{SR}$ provided equal fat and protein contents as $\mathrm{HO}$ in operations with average prevalence, whereas they provided lower fat and protein contents in operations with a high prevalence of disorders. After yr $5, \mathrm{HO} \times \mathrm{MO}, \mathrm{HO} \times \mathrm{MO} \times \mathrm{NO}$, and $\mathrm{HO} \times \mathrm{MO} \times$ SR always provided lower milk yield per cow-year and higher fat and protein contents than HO. At yr 15, in operations with an average prevalence of disorders, deviations from $\mathrm{HO}$ were $-262 \mathrm{~L}$ of milk per cow-year, $0.5 \mathrm{~g} / \mathrm{kg}$ of fat content, and $0.3 \mathrm{~g} / \mathrm{kg}$ of protein content for $\mathrm{HO} \times \mathrm{MO},-442 \mathrm{~L}$ of milk per cow-year, $1.6 \mathrm{~g} / \mathrm{kg}$ of fat content, and $1.2 \mathrm{~g} / \mathrm{kg}$ of protein content for $\mathrm{HO}$ $\times \mathrm{MO} \times \mathrm{NO}$, and $-218 \mathrm{~L}$ of milk per cow-year, $1.5 \mathrm{~g} /$ $\mathrm{kg}$ of fat content, and $0.4 \mathrm{~g} / \mathrm{kg}$ of protein content for $\mathrm{HO} \times \mathrm{MO} \times \mathrm{SR}$. In operations with a high prevalence of disorders, deviations from $\mathrm{HO}$ were $-132 \mathrm{~L}$ of milk

a)

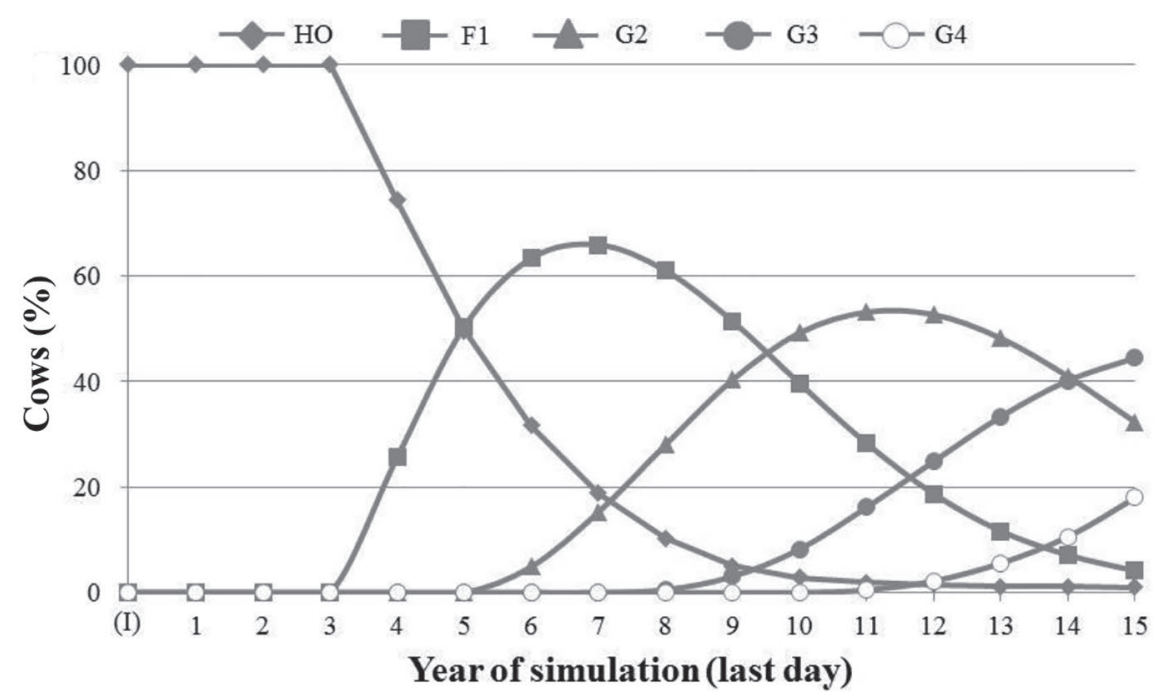

b)

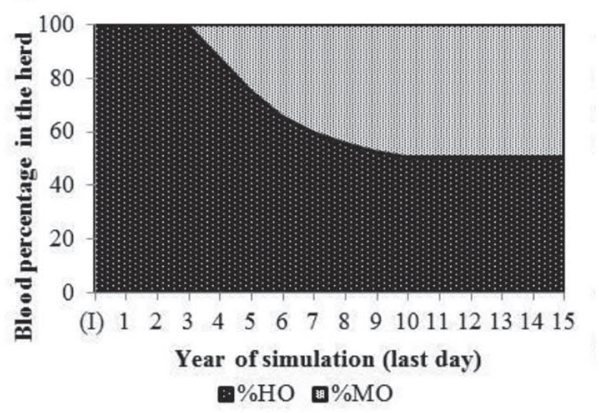

c)

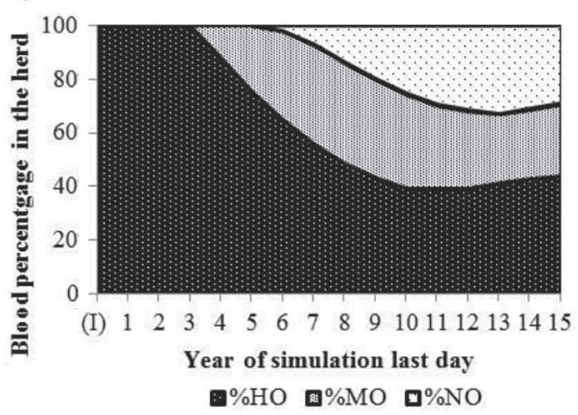

d)

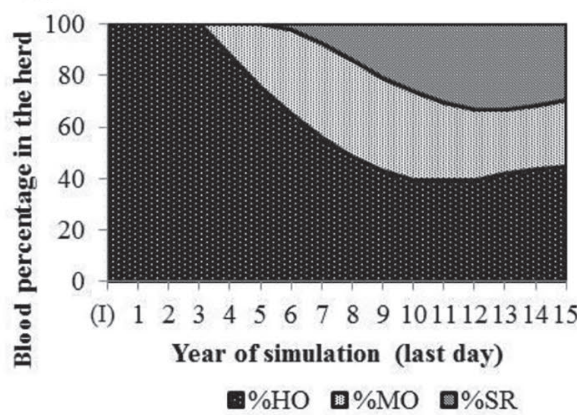

Figure 1. Generations of genotypes of cows at the end of the year for the 3 crossbreeding schemes simulated (a) and blood percentage in the herd for $\mathrm{HO} \times \mathrm{MO}$ scheme $(\mathrm{b}), \mathrm{HO} \times \mathrm{MO} \times \mathrm{NO}$ scheme $(\mathrm{c})$, and $\mathrm{HO} \times \mathrm{MO} \times \mathrm{SR}$ scheme $(\mathrm{d})$ under an objective of constant number of cows over time. $\mathrm{HO}=$ Holstein cows; F1 = first-generation crossbred cows; G2 = second-generation crossbred cows; G3 = third-generation crossbred cows; $\mathrm{G} 4=$ fourth and following generation crossbred cows; $\% \mathrm{HO}=$ percentage of Holstein blood; \% MO = percentage of Montbéliarde blood; $\% \mathrm{NO}=$ percentage of Normande blood; \% $\mathrm{SR}=$ percentage of Scandinavian Red blood; (I) = initial state of the herd at the beginning of the simulation. 

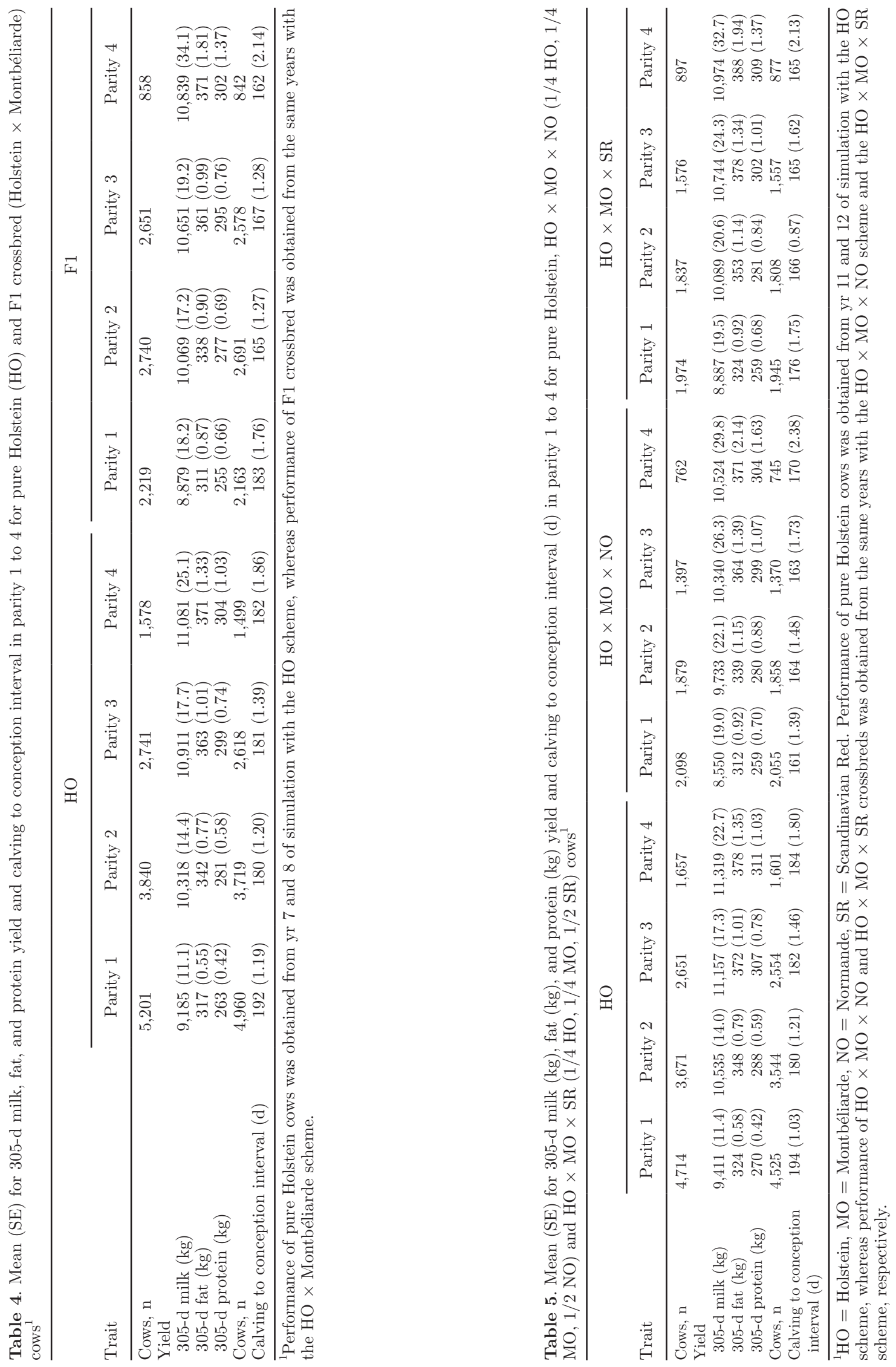
per cow-year, $0.3 \mathrm{~g} / \mathrm{kg}$ of fat content, and $0.1 \mathrm{~g} / \mathrm{kg}$ of protein content for $\mathrm{HO} \times \mathrm{MO},-248 \mathrm{~L}$ of milk per cow-year, $1.2 \mathrm{~g} / \mathrm{kg}$ of fat content, and $0.9 \mathrm{~g} / \mathrm{kg}$ of protein content for $\mathrm{HO} \times \mathrm{MO} \times \mathrm{NO}$, and $-93 \mathrm{~L}$ of milk per cow-year, $1.1 \mathrm{~g} / \mathrm{kg}$ of fat content, and $0.3 \mathrm{~g} / \mathrm{kg}$ of protein content for $\mathrm{HO} \times \mathrm{MO} \times \mathrm{SR}$.

Average Performance for Fertility, Udder Health, and Number of Culled Cows. From yr 1 to $4, \mathrm{HO} \times \mathrm{MO}, \mathrm{HO} \times \mathrm{MO} \times \mathrm{NO}$, and $\mathrm{HO} \times \mathrm{MO} \times$ SR led to higher conception rate (Figure 3), shorter interval from calving to conception $(-4 \mathrm{~d}$ in yr 1 to -8
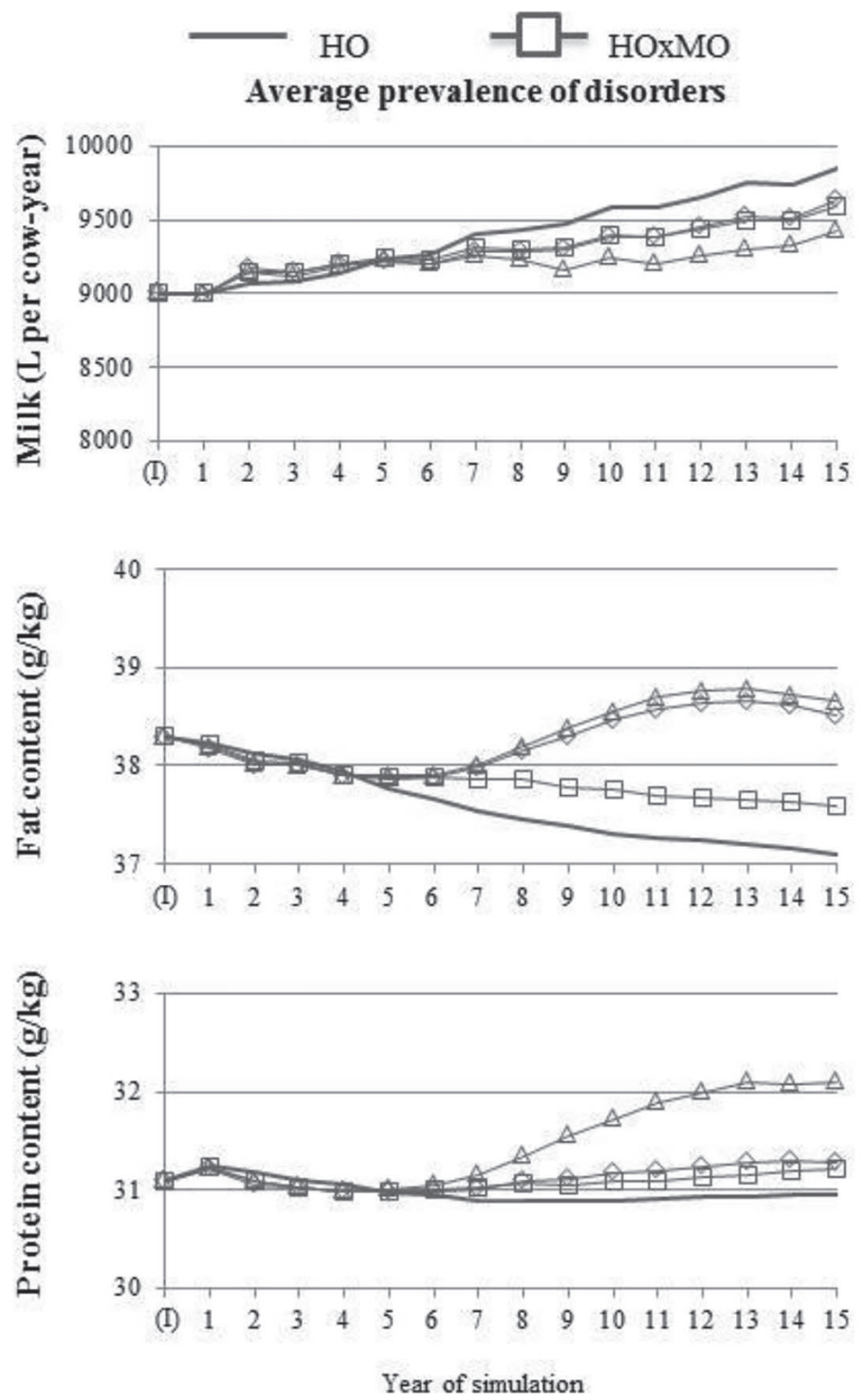

$\mathrm{d}$ in $\mathrm{yr} 4$ ) and lower average stage of lactation in the herd $(-1 \mathrm{~d}$ in yr 1 to $-6 \mathrm{~d}$ in yr 4$)$ than HO. Conception rate and interval from calving to conception was similar between $\mathrm{HO} \times \mathrm{MO}, \mathrm{HO} \times \mathrm{MO} \times \mathrm{NO}$, and $\mathrm{HO} \times \mathrm{MO} \times \mathrm{SR}$. At yr 15, in operations with average and high prevalence of disorders, conception rate was higher (9 and 6 points, respectively; Figure 3), interval from calving to conception was shorter $(-14$ and -19 $\mathrm{d}$, respectively), and average stage of lactation in the herd was shorter $(-6$ and $-11 \mathrm{~d}$, respectively) with crossbreeding than with $\mathrm{HO}$.
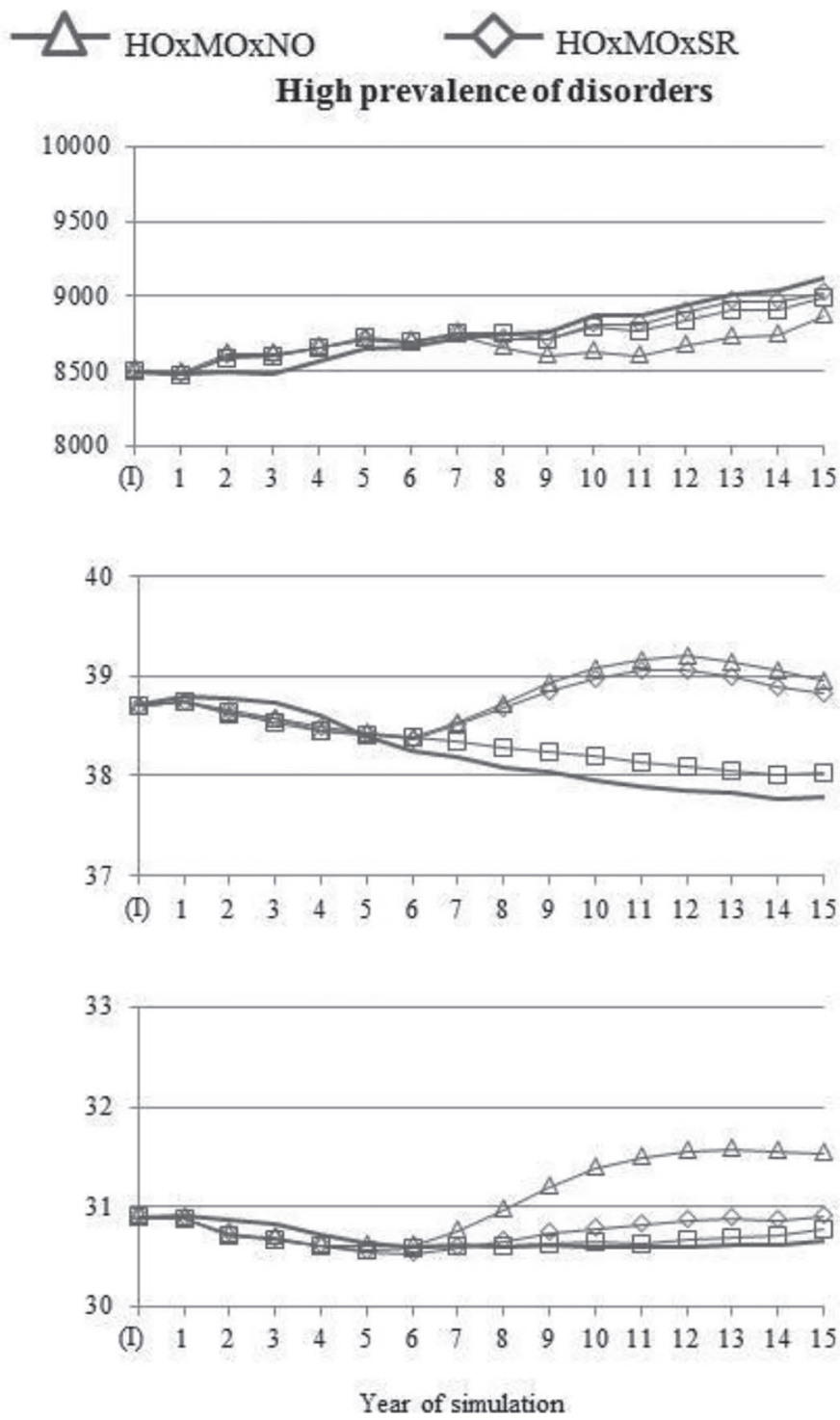

Figure 2. Mean for milk yield per cow-year, milk fat content and protein content according to breeding schemes, and levels in prevalence of health and reproductive disorders under an objective of constant number of cows (SE were between 4.4 and $11.4 \mathrm{~L}$ for milk yield per cow-year, 0.006 and $0.025 \mathrm{~g} / \mathrm{kg}$ for fat content, 0.006 and $0.13 \mathrm{~g} / \mathrm{kg}$ for protein content). $\mathrm{HO}=$ pure breeding Holstein; $\mathrm{HO} \times \mathrm{MO}=2$-breed crossbreeding scheme with Holstein and Montbéliarde breeds; $\mathrm{HO} \times \mathrm{MO} \times \mathrm{NO}=3$-breed crossbreeding scheme with Holstein, Montbéliarde, and Normande breeds; $\mathrm{HO} \times \mathrm{MO} \times \mathrm{SR}=3$-breed crossbreeding scheme with Holstein, Montbéliarde, and Scandinavian Red breeds; (I) $=$ initial state of the herd at the beginning of the simulation. 

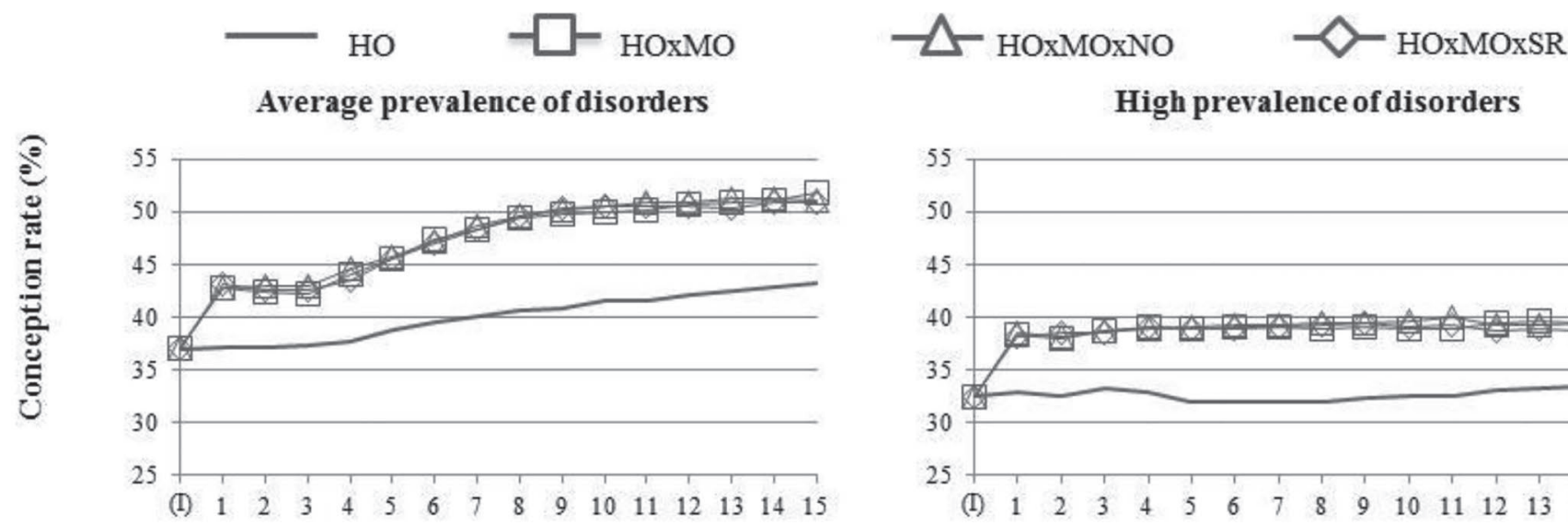

High prevalence of disorders
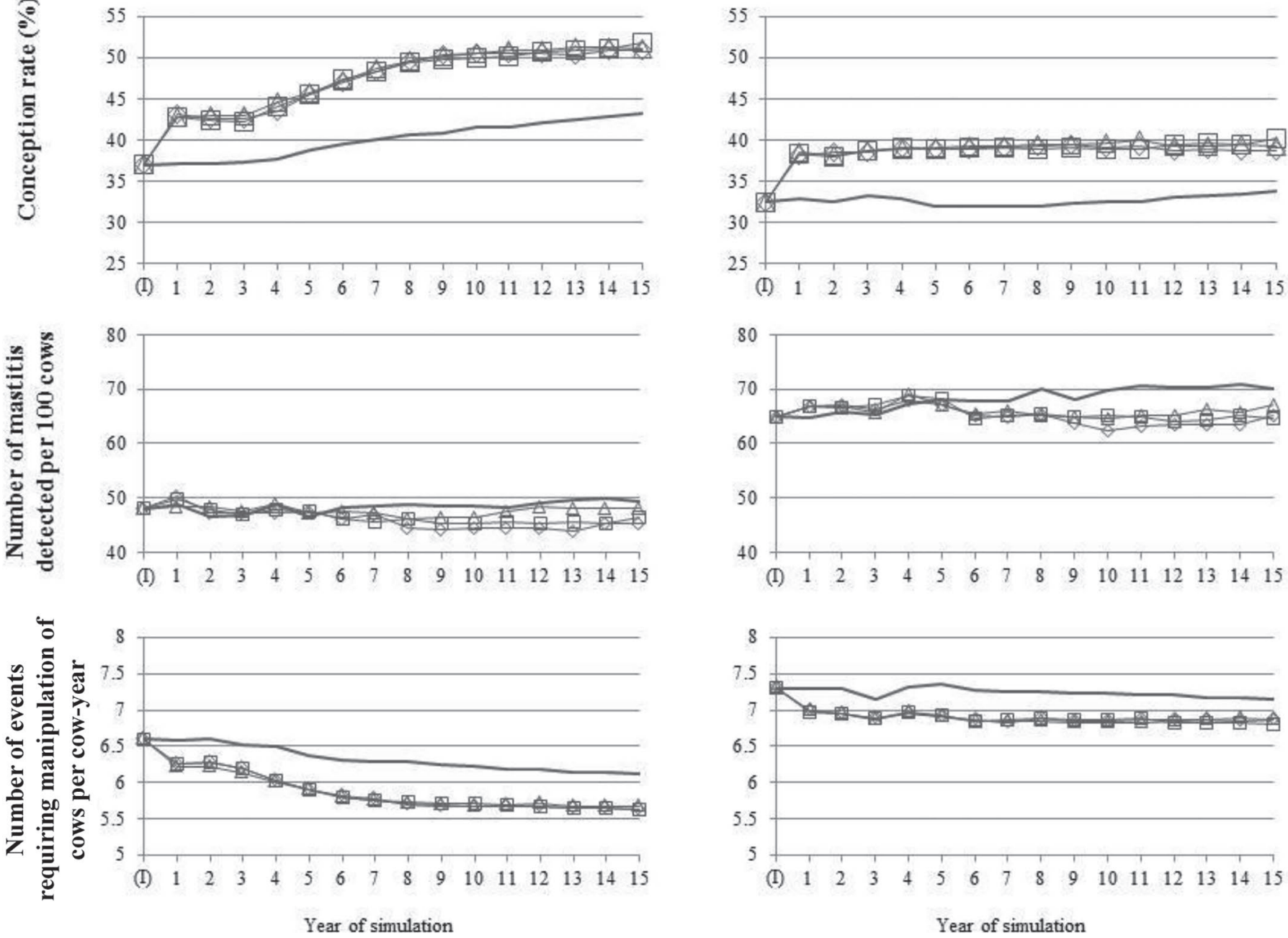

Figure 3. Mean for conception rate, incidence density of clinical mastitis, and number of events requiring manipulation of cows according to breeding schemes and levels in prevalence of health and reproductive disorders under an objective of constant number of cows (SE were between 0.16 and $0.20 \%$ for conception rate, 0.4 and 0.8 cases of mastitis detected per 100 cows, 0.01 and 0.02 events requiring manipulation of cows). $\mathrm{HO}=$ pure breeding Holstein $\mathrm{HO} \times \mathrm{MO}=2$-breed crossbreeding scheme with Holstein and Montbéliarde breeds; $\mathrm{HO} \times \mathrm{MO} \times \mathrm{NO}=3$-breed crossbreeding scheme with Holstein, Montbéliarde, and Normande breeds; $\mathrm{HO} \times \mathrm{MO} \times \mathrm{SR}=3$-breed crossbreeding scheme with Holstein, Montbéliarde, and Scandinavian Red breeds; (I) = initial state of the herd at the beginning of the simulation. The number of events requiring manipulation of cows was computed as an occurrence counter for AI, treatments for mastitis or infertility, and calving events.

Differences in clinical mastitis incidence density between crossbreeding and $\mathrm{HO}$ appeared after yr 5 (Figure 3). At yr 15, in operations with average and high prevalence of disorders, clinical mastitis incidence density was equal between $\mathrm{HO} \times \mathrm{MO}$ and $\mathrm{HO} \times \mathrm{MO}$ $\times$ SR (46 and 65 cases/100 cow-year, respectively) and lower than HO (49 and 70 cases/100 cow-year, respectively) $\mathrm{HO} \times \mathrm{MO} \times \mathrm{NO}$ was intermediate $(48$ and 68 cases/100 cow-year, respectively).

Differences in number of culled cows between crossbreeding and $\mathrm{HO}$ were mainly affected by prevalence of disorders and appeared after yr 5 (Figure 4). At yr 15 , in operations with average prevalence of disorders, $\mathrm{HO} \times \mathrm{MO}, \mathrm{HO} \times \mathrm{MO} \times \mathrm{NO}$, and $\mathrm{HO} \times \mathrm{MO} \times \mathrm{SR}$ led to -3 and -4 culled cows per 100 cow-years under an objective of constant number of cows and an objective of constant volume of milk sold, respectively. At yr 15, in dairy operations with a high prevalence of disorders, number of culled cows per 100 cow-years was almost not different between $\mathrm{HO} \times \mathrm{MO}, \mathrm{HO} \times \mathrm{MO} \times \mathrm{NO}, \mathrm{HO}$ $\times \mathrm{MO} \times \mathrm{SR}$, and $\mathrm{HO}$ schemes under both management objectives. 

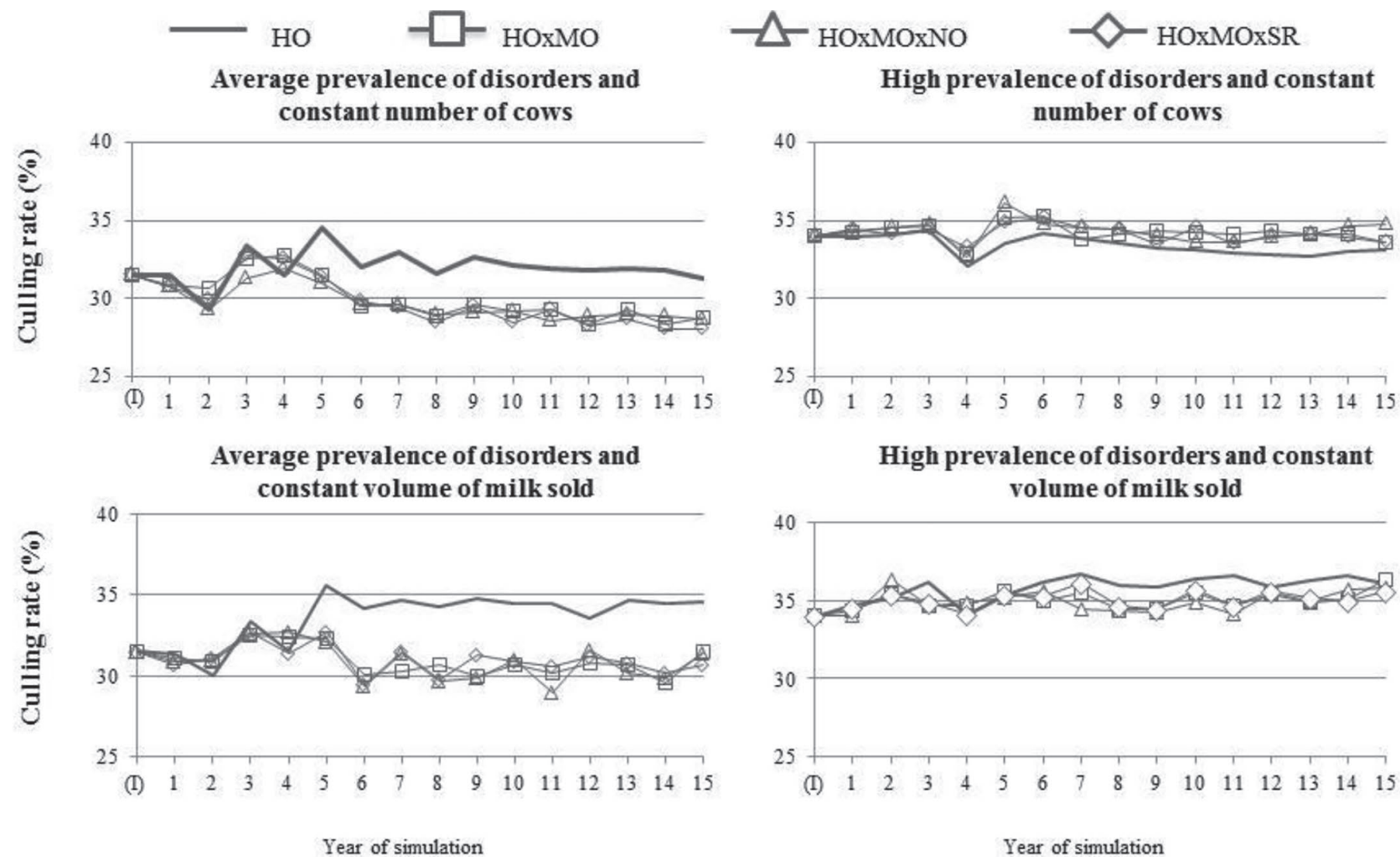

High prevalence of disorders and constant volume of milk sold

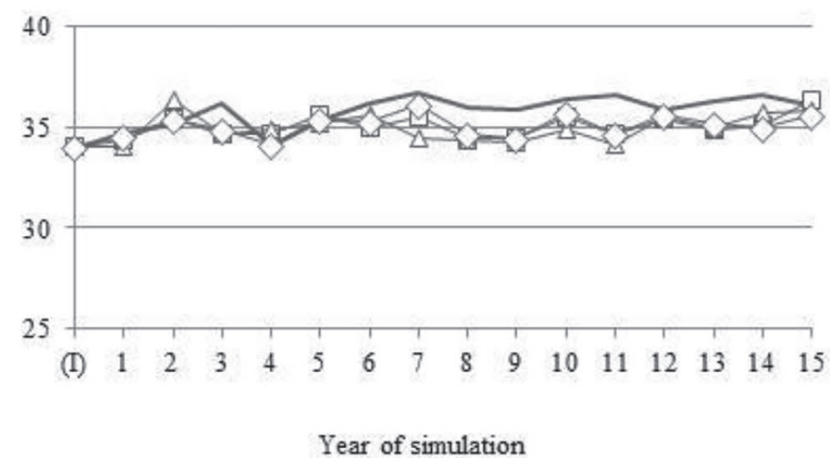

Figure 4. Mean for number of culled cows per 100 cow-years according to breeding schemes and levels in prevalence of health and reproductive disorders under an objective of constant number of cows or volume of milk sold (SE were between 0.16 and $0.35 \%$ ). HO = pure breeding Holstein; $\mathrm{HO} \times \mathrm{MO}=2$-breed crossbreeding scheme with Holstein and Montbéliarde breeds; $\mathrm{HO} \times \mathrm{MO} \times \mathrm{NO}=3$-breed crossbreeding scheme with Holstein, Montbéliarde, and Normande breeds; $\mathrm{HO} \times \mathrm{MO} \times \mathrm{SR}=3$-breed crossbreeding scheme with Holstein, Montbéliarde, and Scandinavian Red breeds; (I) = initial state of the herd at the beginning of the simulation.

\section{Average Number of Cows and Workload for Cow Manipulation or Treatment}

After $15 \mathrm{yr}$, under an objective of constant volume of milk sold, the initial barn was filled at $92,97,98$, and $96 \%$ with $\mathrm{HO}, \mathrm{HO} \times \mathrm{MO}, \mathrm{HO} \times \mathrm{MO} \times \mathrm{NO}$, and $\mathrm{HO} \times$ $\mathrm{MO} \times \mathrm{SR}$, respectively, for both levels in prevalence of disorders. From yr 1, the number of events was similar between $\mathrm{HO} \times \mathrm{MO}, \mathrm{HO} \times \mathrm{MO} \times \mathrm{NO}$, and $\mathrm{HO} \times \mathrm{MO}$ $\times$ SR and lower than HO (Figure 3 ). At yr 15, in operations with average and high prevalence of disorders, the number of events was similar between $\mathrm{HO} \times \mathrm{MO}, \mathrm{HO}$ $\times \mathrm{MO} \times \mathrm{NO}$, and $\mathrm{HO} \times \mathrm{MO} \times \mathrm{SR}\left(5.6\right.$ and $6.8 / \mathrm{cow}^{-}$ year, respectively) and lower than $\mathrm{HO}$ (6.1 and 7.1/ cow-year, respectively).

\section{Average Revenues and Variable Costs}

Crossbreeding schemes $\mathrm{HO} \times \mathrm{MO}, \mathrm{HO} \times \mathrm{MO} \times$ $\mathrm{NO}$, and $\mathrm{HO} \times \mathrm{MO} \times \mathrm{SR}$ provided slightly lower milk prices, from yr 1 to 4 , and higher milk prices, from yr
5 to 15 , than HO (Figure 5). Under an objective of constant number of cows, in operations with an average prevalence of disorders, $\mathrm{HO} \times \mathrm{MO}, \mathrm{HO} \times \mathrm{MO} \times \mathrm{NO}$, and $\mathrm{HO} \times \mathrm{MO} \times \mathrm{SR}$ provided higher revenues than $\mathrm{HO}$ from yr 1 to 4 (Table 6). Both $\mathrm{HO} \times \mathrm{MO}$ and $\mathrm{HO}$ $\times \mathrm{MO} \times \mathrm{NO}$ provided lower revenues from yr 5 to 15 , and $\mathrm{HO} \times \mathrm{MO} \times \mathrm{SR}$ from yr 10 to 15 , than $\mathrm{HO}$. For the whole period, revenues for $\mathrm{HO}, \mathrm{HO} \times \mathrm{MO}$, and $\mathrm{HO} \times \mathrm{MO} \times \mathrm{NO}$ were of the same magnitude, whereas $\mathrm{HO} \times \mathrm{MO} \times \mathrm{SR}$ had greater revenues. Schemes HO $\times \mathrm{MO}, \mathrm{HO} \times \mathrm{MO} \times \mathrm{NO}$, and $\mathrm{HO} \times \mathrm{MO} \times \mathrm{SR}$ had lower variable costs than $\mathrm{HO}$. In operations with a high prevalence of disorders, $\mathrm{HO} \times \mathrm{MO}, \mathrm{HO} \times \mathrm{MO} \times \mathrm{NO}$, and $\mathrm{HO} \times \mathrm{MO} \times \mathrm{SR}$ had higher revenues and lower variable costs than $\mathrm{HO}$ for the 3 periods.

Under an objective of constant volume of milk sold, $\mathrm{HO} \times \mathrm{MO}, \mathrm{HO} \times \mathrm{MO} \times \mathrm{NO}$, and $\mathrm{HO} \times \mathrm{MO} \times \mathrm{SR}$ had higher revenues and lower variable costs than $\mathrm{HO}$ in operations with an average prevalence of disorders for the 3 periods (Table 7 ). Schemes $\mathrm{HO} \times \mathrm{MO}, \mathrm{HO} \times$ $\mathrm{MO} \times \mathrm{NO}$, and $\mathrm{HO} \times \mathrm{MO} \times \mathrm{SR}$ had higher revenues 
and similar variable costs than $\mathrm{HO}$ in operations with a high prevalence of disorders for the 3 periods.

\section{Average Margin Over Variable Costs}

Under an objective of constant number of cows, HO $\times \mathrm{MO}, \mathrm{HO} \times \mathrm{MO} \times \mathrm{NO}$, and $\mathrm{HO} \times \mathrm{MO} \times \mathrm{SR}$ led to greater discounted margin over variable costs for the 3 periods (Table 6). In operations with a high prevalence of disorders, differences increased over time from $1.5 \%$ during the first 4 yr to higher than $6 \%$ during yr 10 to 15. In operations with an average prevalence of disorders, differences also increased over time but were lower than $1.5 \%$. Over the whole period, $\mathrm{HO} \times \mathrm{MO} \times \mathrm{SR}$ provided the greatest margin over variable costs.

Under an objective of constant volume of milk sold, $\mathrm{HO} \times \mathrm{MO}, \mathrm{HO} \times \mathrm{MO} \times \mathrm{NO}$, and $\mathrm{HO} \times \mathrm{MO} \times \mathrm{SR}$ led to greater discounted margin over variable costs for the 3 periods (Table 7 ). In operations with an average prevalence of disorders, differences increased over time from $1 \%$ during the first $4 \mathrm{yr}$ to higher than $5 \%$ during yr 10 to 15 . In operations with a high prevalence of disorders, differences increased over time from 1\% during the first $4 \mathrm{yr}$ up to $10 \%$ during year 10 to 15 . Over the whole period, $\mathrm{HO} \times \mathrm{MO} \times \mathrm{NO}$ provided the greatest margin over variable costs.

\section{Sensitivity of Margin Over Variable Costs to Price Context}

Of course, lower milk price and higher concentrate price decreased discounted margin over variable costs for all breeding schemes, and reverse effects were observed for higher milk price and lower concentrates price (Table 8). Under an objective of constant number of cows, deviations of margins provided by crossbreeding schemes (from that of the HO scheme) were similar or somewhat larger for the unfavorable pricing context, in comparison with the default pricing context (up to $€ 14$ more/cow-year in deviation from $\mathrm{HO}$ ). Under that same objective, higher milk price and lower concentrate price led to quite similar effects than the default pricing context, excepted for $\mathrm{HO} \times \mathrm{MO} \times \mathrm{SR}$, which gained $€ 9$ more/cow-year in operations with high prevalence of disorders. Under an objective of constant volume of milk sold, the unfavorable context, the deviation of margins provided by crossbreeding schemes tended to decrease, and the reverse trend was observed for favorable pricing contexts, with a difference in deviation up to $€ 1.9 / 1,000 \mathrm{~L}$ (corresponding to $€ 17 /$ cow-year).

\section{DISCUSSION}

From a dynamic, mechanistic, and stochastic simulation model, we assessed the interest of introducing different crossbreeding schemes in Holstein operations with different initial reproductive and health statuses, with different management objectives, and under different economic contexts. Our results confirmed the relevance of studying these interactions. We were also able to show how performance and profitability differed in magnitude within the $15 \mathrm{yr}$ studied.

Validity of the results presented here is, of course, dependent on the validity of the model developed. The simulation model represented the biologic processes occurring during a lactation-reproduction cycle at the animal level in a quite detailed way (i.e., based on individual genetic value and individual or herd-level nonpermanent effects). A stochastic approach was used

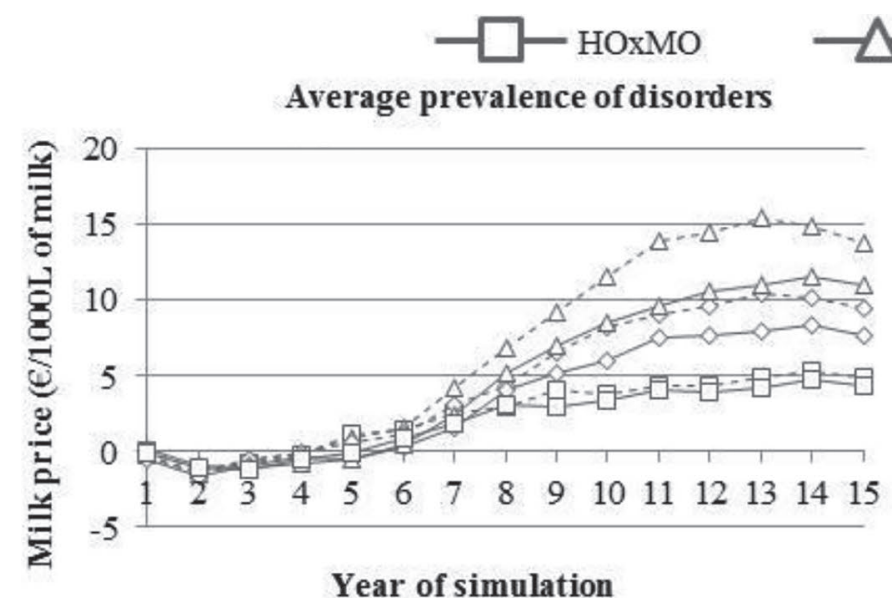

HOXMOXNO

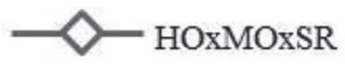

High prevalence of disorders

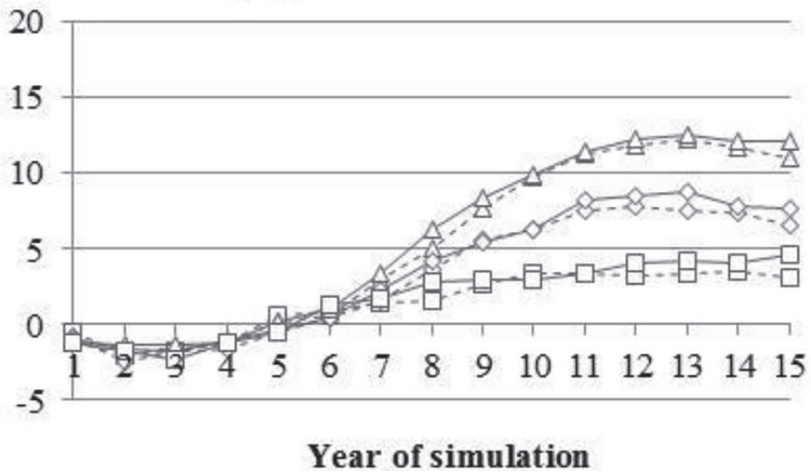

Figure 5. Average deviation of milk selling price (€/1,000 L of milk) of crossbreeding schemes compared with pure Holstein scheme according to prevalence of disorders under the objective of constant number of cows $(-)$ and constant volume of milk sold $(---)$. HO $\times$ MO $=2$-breed crossbreeding scheme with Holstein and Montbéliarde breeds; $\mathrm{HO} \times \mathrm{MO} \times \mathrm{NO}=3$-breed crossbreeding scheme with Holstein, Montbéliarde, and Normande breeds; $\mathrm{HO} \times \mathrm{MO} \times \mathrm{SR}=3$-breed crossbreeding scheme with Holstein, Montbéliarde, and Scandinavian Red breeds. 
to deal with reproductive and health processes and to simulate their occurrence and consequences on milk production, reproducing part of the variability encountered in real life. Most influential managerial options or decisions of the farmer were integrated in a quite realistic way, based on the resulting effects. Individual performance was summed to get herd-level performance. Usually, models for complex systems are often difficult to fully validate. Classical validation by comparison to an independent set of data was not particularly applicable, given that no corresponding data exist; thus, only partial elements of validation could be considered. Nevertheless, general consistency of outcomes and their a priori validity was considered improved by computing mechanistically the daily individual phenotypic performance of each cow. Partial validation steps were done by checking the results of Holstein cows in comparison with crossbred cows. In our findings, F1 cows produced less 305-d milk, fat, and protein yields and had shorter calving to conception intervals than Holstein ones. The differences between Holstein and F1 cows were smaller than in Heins et al. (2006a,b) and Dezetter et al. (2015) and higher than in Walsh and al. (2008), but stayed of the same magnitude. Second-generation crossbred cows produced even less milk than F1 cows compared with Holstein cows, especially those of the Normande breed. The genetic gain applied on sires for milk yield explained why differences between crossbred types and Holstein increased over time. The $\mathrm{HO} \times \mathrm{MO} \times \mathrm{SR}$ second-generation crossbred cows produced more fat than Holstein cows, probably due to the higher EBV for fat of SR sires.

Table 6. Mean ${ }^{1}$ and SE for revenues ( $€ /$ cow-year), variable costs $(€ /$ cow-year $)$, and discounted margin over variable costs $(€ /$ cow-year) according to breeding schemes and levels in prevalence of disorders under an objective of constant number of cows ${ }^{2}$

\begin{tabular}{|c|c|c|c|c|c|c|c|c|}
\hline \multirow[b]{2}{*}{ Scenarios and period } & \multicolumn{2}{|c|}{$\mathrm{HO}$} & \multicolumn{2}{|c|}{$\mathrm{HO} \times \mathrm{MO}$} & \multicolumn{2}{|c|}{$\mathrm{HO} \times \mathrm{MO} \times \mathrm{NO}$} & \multicolumn{2}{|c|}{$\mathrm{HO} \times \mathrm{MO} \times \mathrm{SR}$} \\
\hline & Mean & $\mathrm{SE}$ & Mean & $\mathrm{SE}$ & Mean & $\mathrm{SE}$ & Mean & $\mathrm{SE}$ \\
\hline \multicolumn{9}{|l|}{$1-4$ yr } \\
\hline Revenue & 3,538 & 2.1 & 27 & 2.1 & 15 & 1.9 & 30 & 2.0 \\
\hline Variable cost & 980 & 0.9 & -10 & 0.9 & -11 & 0.9 & -10 & 0.8 \\
\hline Discounted margin over variable cost & 2,382 & 1.7 & 16 & 1.8 & 10 & 1.6 & 22 & 1.8 \\
\hline Variable cost & 992 & 0.9 & -28 & 0.9 & -29 & 0.9 & -30 & 0.9 \\
\hline Discounted margin over variable cost & 2,148 & 1.9 & 23 & 2.0 & 18 & 2.2 & 24 & 2.2 \\
\hline \multicolumn{9}{|l|}{$10-15$ yr } \\
\hline Revenue & 3,730 & 2.5 & -9 & 2.3 & -6 & 2.3 & 27 & 2.5 \\
\hline Variable cost & 1,009 & 0.9 & -38 & 0.8 & -48 & 0.8 & -40 & 0.8 \\
\hline Discounted margin over variable cost & 1,881 & 1.6 & 19 & 1.6 & 27 & 1.4 & 45 & 1.5 \\
\hline \multicolumn{9}{|l|}{$1-15 \mathrm{yr}$} \\
\hline \multicolumn{9}{|l|}{$1-4$ yr } \\
\hline Revenue & 3,224 & 2.3 & 13 & 2.3 & 16 & 2.3 & 16 & 2.3 \\
\hline Variable cost & 1,044 & 0.9 & -13 & 0.9 & -10 & 0.9 & -13 & 0.9 \\
\hline Discounted margin over variable cost & 2,022 & 2.0 & 29 & 2.1 & 29 & 2.1 & 31 & 2.0 \\
\hline \multicolumn{9}{|l|}{$5-9$ yr } \\
\hline Revenue & 3,240 & 3.7 & 97 & 4.0 & 102 & 3.9 & 100 & 3.8 \\
\hline Variable cost & 1,060 & 1.1 & -14 & 1.1 & -13 & 1.0 & -14 & 1.0 \\
\hline Discounted margin over variable cost & 1,770 & 2.3 & 94 & 2.6 & 96 & 2.5 & 96 & 2.5 \\
\hline \multicolumn{9}{|l|}{$10-15$ yr } \\
\hline Revenue & 3,297 & 4.1 & 112 & 3.7 & 118 & 3.6 & 168 & 3.9 \\
\hline Variable cost & 1,072 & 1.1 & -21 & 1.0 & -26 & 1.0 & -16 & 1.1 \\
\hline Discounted margin over variable cost & 1,539 & 2.3 & 92 & 2.1 & 98 & 2.0 & 126 & 2.3 \\
\hline \multicolumn{9}{|l|}{$1-15$ yr } \\
\hline Revenue & 3,259 & 2.3 & 81 & 2.3 & 85 & 2.2 & 105 & 2.2 \\
\hline Variable cost & 1,060 & 0.8 & -17 & 0.9 & -17 & 0.8 & -14 & 0.9 \\
\hline
\end{tabular}

${ }^{1}$ Mean of margin over variable costs per year was discounted to a net present value at a rate of $3 \%$ per annum and computed as revenues minus variable costs without accounting for differences in roughage production costs. However, costs were adjusted when differences of roughage intake between crossbreeding and pure breeding schemes were over $4 \%$.

${ }^{2}$ Results from crossbreeding schemes are given in deviation from Holstein pure breeding. $\mathrm{HO}=$ pure breeding Holstein; $\mathrm{HO} \times \mathrm{MO}=2$-breed crossbreeding scheme with Holstein and Montbéliarde breeds; $\mathrm{HO} \times \mathrm{MO} \times \mathrm{NO}=3$-breed crossbreeding scheme with Holstein, Montbéliarde, and Normande breeds; $\mathrm{HO} \times \mathrm{MO} \times \mathrm{SR}=3$-breed crossbreeding scheme with Holstein, Montbéliarde, and Scandinavian Red breeds. 
Outcomes of any simulation experiment depend on parameterization. Here, choices for genetic parameters affected the results. Parameters for breed differences and heterosis effects on milk yield, fat and protein contents of milk, and conception rate were those estimated by across-breed evaluations between Holstein, Montbéliarde, and Normande breeds (Dezetter et al., 2015) and between Holstein and Scandinavian Red (Jönsson, 2015). Due to lack of data, default options were needed. First, the heterosis effect on clinical mastitis was arbitrarily set to 0 and crossbreeding effects on other health traits were not modeled because of a lack of data. However, heritability of health traits being low (Uribe et al., 1995; Zwald et al., 2004), heterosis effects on these traits might be significant (Lynch and Walsh, 1998). Inbreeding depression was also not modeled, even if crossbreeding is known to be a way to decrease its effect (Dickerson, 1973). As our objective was to compare different breeding schemes in Holstein operations, we did not consider uncertainty relative to parameter values, which were assumed to be constant over time. Choosing sires with high EBV for milk yield led to the observed results on milk fat and protein contents, with a decreasing trend over time with the $\mathrm{HO}$ and $\mathrm{HO} \times \mathrm{MO}$ schemes. This choice was made because we set the yield of initial Holstein herds above the current level of French herds and made the consistent assumption that introduction of crossbreeding in such dairy operations will not necessarily induce a substantial change in priority for selection. This choice benefitted within-breed genetic improvement, especially because the differences in genetic progress are not the same among breeds. Such a choice was also justified by the plausible assumption that if crossbreeding can

Table 7. Mean ${ }^{1}$ and SE from 250 replications for revenues $(€ / 1,000 \mathrm{~L} / \mathrm{yr})$, variable costs $(€ / 1,000 \mathrm{~L} / \mathrm{yr})$ and discounted margin over variable costs $(€ / 1,000 \mathrm{~L} / \mathrm{yr})$ according to breeding schemes and levels in prevalence of disorders under an objective of constant volume of milk sold ${ }^{2}$

\begin{tabular}{|c|c|c|c|c|c|c|c|c|}
\hline \multirow[b]{2}{*}{ Scenario and period } & \multicolumn{2}{|c|}{$\mathrm{HO}$} & \multicolumn{2}{|c|}{$\mathrm{HO} \times \mathrm{MO}$} & \multicolumn{2}{|c|}{$\mathrm{HO} \times \mathrm{MO} \times \mathrm{NO}$} & \multicolumn{2}{|c|}{$\mathrm{HO} \times \mathrm{MO} \times \mathrm{SR}$} \\
\hline & Mean & $\mathrm{SE}$ & Mean & $\mathrm{SE}$ & Mean & $\mathrm{SE}$ & Mean & $\mathrm{SE}$ \\
\hline \multicolumn{9}{|l|}{ Average prevalence of disorders } \\
\hline Revenue & 381.3 & 0.23 & 3.7 & 0.21 & 4.3 & 0.22 & 3.9 & 0.20 \\
\hline Variable cost & 105.5 & 0.09 & -1.2 & 0.08 & -1.2 & 0.09 & -1.4 & 0.08 \\
\hline Discounted margin over variable cost & 256.9 & 0.19 & 2.5 & 0.18 & 3.0 & 0.20 & 2.9 & 0.18 \\
\hline Variable cost & 104.2 & 0.09 & -1.2 & 0.09 & -0.9 & 0.09 & -1.6 & 0.08 \\
\hline Discounted margin over variable cost & 225.1 & 0.20 & 7.5 & 0.21 & 10.0 & 0.21 & 8.2 & 0.20 \\
\hline \multicolumn{9}{|l|}{$10-15$ yr } \\
\hline Revenue & 379.3 & 0.24 & 13.2 & 0.22 & 21.0 & 0.20 & 16.3 & 0.19 \\
\hline Variable cost & 102.6 & 0.09 & -0.7 & 0.08 & -0.8 & 0.08 & -1.7 & 0.08 \\
\hline Discounted margin over variable cost & 191.2 & 0.16 & 9.6 & 0.15 & 15.0 & 0.13 & 12.3 & 0.11 \\
\hline \multicolumn{9}{|l|}{$1-15$ yr } \\
\hline Revenue & 366.7 & 0.22 & 3.9 & 0.23 & 4.1 & 0.23 & 3.3 & 0.20 \\
\hline Variable cost & 118.5 & 0.10 & -0.7 & 0.11 & -0.6 & 0.10 & -0.9 & 0.11 \\
\hline Discounted margin over variable cost & 229.9 & 0.20 & 5.0 & 0.21 & 5.1 & 0.20 & 4.8 & 0.19 \\
\hline \multicolumn{9}{|l|}{$5-9$ yr } \\
\hline Revenue & 361.9 & 0.30 & 15.5 & 0.30 & 17.6 & 0.37 & 16.3 & 0.35 \\
\hline Variable cost & 118.1 & 0.11 & 0.2 & 0.11 & 0.6 & 0.11 & -0.1 & 0.10 \\
\hline Discounted margin over variable cost & 197.9 & 0.20 & 12.9 & 0.20 & 14.3 & 0.25 & 13.5 & 0.25 \\
\hline \multicolumn{9}{|l|}{$10-15 \mathrm{yr}$} \\
\hline Revenue & 360.0 & 0.29 & 20.3 & 0.34 & 26.3 & 0.32 & 21.8 & 0.33 \\
\hline Variable cost & 116.4 & 0.11 & 0.8 & 0.11 & 1.0 & 0.10 & -0.3 & 0.11 \\
\hline Discounted margin over variable cost & 168.2 & 0.16 & 13.5 & 0.20 & 17.5 & 0.19 & 15.2 & 0.21 \\
\hline \multicolumn{9}{|l|}{$1-15 \mathrm{yr}$} \\
\hline Revenue & 362.4 & 0.16 & 14.3 & 0.19 & 17.5 & 0.18 & 15.0 & 0.19 \\
\hline
\end{tabular}

${ }^{1}$ Means of margin over variable costs per year were discounted to a net present value at a rate of $3 \%$ per annum and computed as revenues minus variable costs without accounting for differences in roughage production costs. However, costs were adjusted when differences of roughage intake between crossbreeding and pure breeding schemes were over $4 \%$.

${ }^{2}$ Results from crossbreeding schemes are given in deviation from Holstein pure breeding. $\mathrm{HO}=$ pure breeding $\mathrm{Holstein} ; \mathrm{HO} \times \mathrm{MO}=2$-breed crossbreeding scheme with Holstein and Montbéliarde breeds; $\mathrm{HO} \times \mathrm{MO} \times \mathrm{NO}=3$-breed crossbreeding scheme with Holstein, Montbéliarde, and Normande breeds; $\mathrm{HO} \times \mathrm{MO} \times \mathrm{SR}=3$-breed crossbreeding scheme with Holstein, Montbéliarde, and Scandinavian Red breeds. 
Table 8. Mean ${ }^{1}$ and SE from 250 replications for discounted margin over variable costs averaged per cow year (€/cow-year) or per $1,000 \mathrm{~L} / \mathrm{yr}$ $(€ / 1,000 \mathrm{~L} / \mathrm{yr})$ for the whole period, according to breeding schemes, in dairy operations with average (AP) and high (HP) prevalence of disorders under 3 different economic contexts ${ }^{2}$

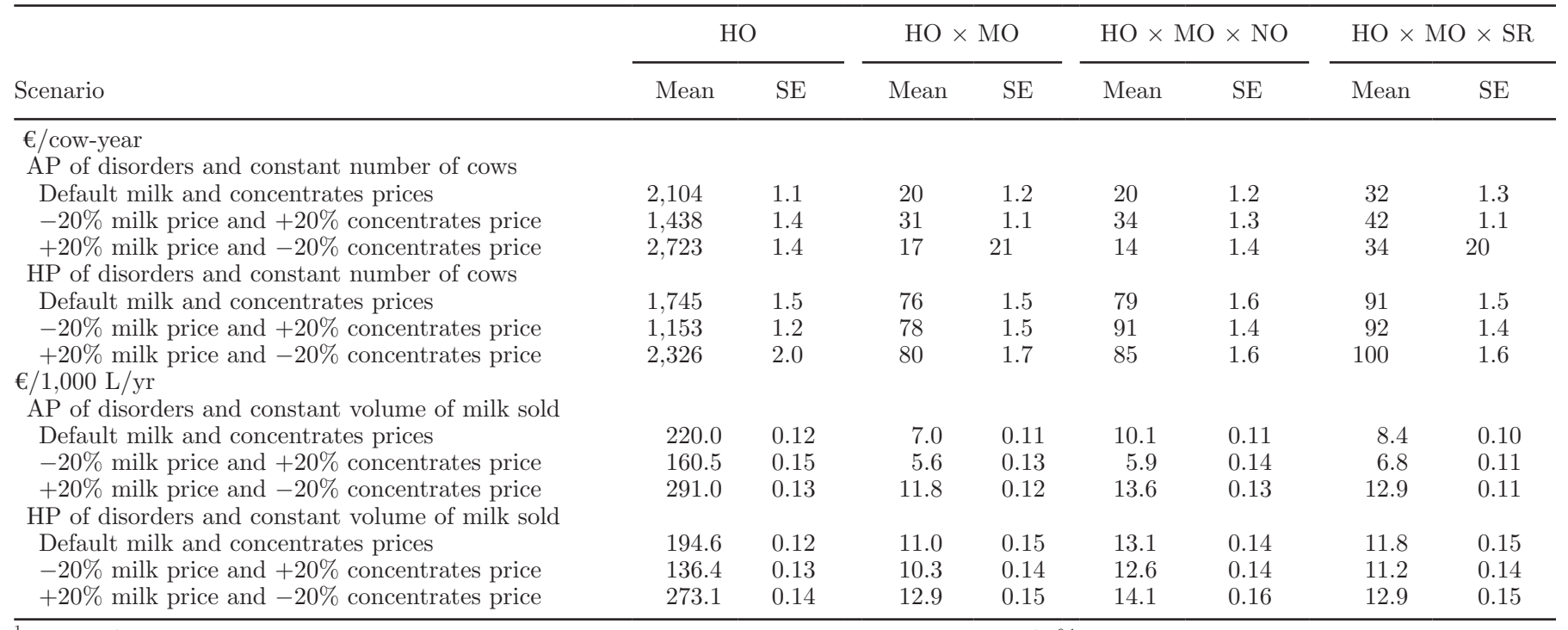

${ }^{1}$ Means of margin over variable costs per year were discounted to a net present value at a rate of $3 \%$ per annum and computed as revenues minus variable costs without accounting for differences in roughage production costs. However, costs were adjusted when differences of roughage intake between crossbreeding and pure breeding schemes were over $4 \%$.

${ }^{2}$ Results from crossbreeding schemes are given in deviation from Holstein pure breeding. $\mathrm{HO}=$ pure breeding Holstein; $\mathrm{HO} \times \mathrm{MO}=2$-breed crossbreeding scheme with Holstein and Montbéliarde breeds; $\mathrm{HO} \times \mathrm{MO} \times \mathrm{NO}=3$-breed crossbreeding scheme with Holstein, Montbéliarde, and Normande breeds; $\mathrm{HO} \times \mathrm{MO} \times \mathrm{SR}=3$-breed crossbreeding scheme with Holstein, Montbéliarde, and Scandinavian Red breeds.

be profitable in high-producing Holstein herds, this will also be true in initial Holstein herds where lower selection priority had already been given to yield. Another choice for sires' selection might have led to other numerical results. For instance, with the initial herds used, selecting sires with lower merit for yield would have generated a relative loss of milk produced per cow. Choices on annual genetic gains, made after discussion with French experts in the field to make them realistic (D. Boichard and V. Ducrocq, Institut National de la Recherche Agronomique, Jouy en Josas, France; personal communication), also affected our results, with an improvement on conception rate even with the HO scheme. Moreover, we applied heterosis estimates for F1 Holstein $\times$ Montbéliarde cows (Dezetter et al., $2015)$ to all crossbred cows. In fact, 3-breed crossbreeding schemes likely lead to higher heterosis effects than 2-breed crossbreeding schemes (Jonhson et al., 1978; Robison et al., 1981). All these choices applied probably led to a slight underestimation of the benefits of all crossbreeding schemes, but seemed not to invalidate our conclusions in favor of crossbreeding, at least for the Holstein operations. Nevertheless, further studies providing complementary parameter values, or using different sires' choices, are needed to quantify more accurately the benefits studied here.

In our results, after $15 \mathrm{yr}$ of simulation, the 2-breed scheme led to an equilibrium in breed percentages in the herd, but not the 3-breed schemes; however, with 3-breed schemes, most benefits of crossbreeding were already obtained. Over $15 \mathrm{yr}$, we showed that profitability of studied Holstein operations improved by crossbreeding. Indeed, as roughage production and fixed costs were identical between scenarios, differences in margin over variable costs are here differences in net profit.

From yr 2 to 5 , crossbreeding schemes provided a bit unexpectedly higher milk yield per cow-year and lower milk fat and protein contents than the Holstein scheme. This is explained by the better success of services with Montbéliarde sires on Holstein cows, leading to more Holstein cows in early lactation per year. After yr 5, milk fat and protein contents, fertility, and udder health were better with crossbreeding schemes than with Holstein scheme, but with less milk produced per cow. Our results also showed a decrease up to 0.5 stressful events per cow-year requiring manipulation of cows; this might seem low, but the reduction of stressful events might be a strong request from some farmers and may can have an effect on farmers' decision to introduce crossbreeding in their Holstein herd. Culling rate was lower with crossbreeding schemes, except in operations with a high prevalence of disorders and under a constant number of cows. One hypothesis is that, in our simulation, we prioritized on-farm rearing versus purchasing replacement heifers, and this could have led 
to have a slightly higher number of heifer calvings per year and to a slightly higher replacement rate.

Globally, as well as under the parametrization applied to our study, all crossbreeding schemes provided, on average, a small to quite substantial increase of discounted margin over variable costs. It should be remembered that estimates for such a margin improvement are also direct gains in profit, given our assumptions for simulations. For the default value pricing system, profit was thus, in discounted value for $15 \mathrm{yr}$, improved from $€ 20$ to $€ 117 /$ cow-year ( $€ 13 / 1,000$ L of milk sold), on average, from 250 replications. The magnitude of variation between simulation replications was limited, and our results indicate that crossbreeding would just be quite neutral in terms of effect on profit in the worst cases here encountered.

Increasing cows' robustness largely compensated for increasing the number of cows needed to produce the same volume of milk sold under that objective. Variable costs were reduced and milk sales revenues were increased with crossbreeding schemes. Indeed, increasing milk fat and protein contents contributed a lot to increase profit, which is consistent with several studies (Veerkamp et al., 2002; VanRaden, 2004); however, increasing the number of cows might increase daily labor. Under a constant number of cows, the benefits on profit were lower in dairy operations with an average prevalence of disorders than with a high prevalence of disorders. This is explained by a larger decrease in the volume of milk sold, for average as opposed to high prevalence of disorders. Indeed, in operations with a high prevalence of disorders, reducing calving interval led to a shorter average stage of lactation and limited the decrease in the volume of milk sold per year.

Direct comparison of our estimates for changes in profit with those provided by Lopez-Villalobos et al. (2000) and Heins et al. (2012) appears not very relevant to implement. First, we focused typically on the transitory phase when these studies considered only the stabilized phase or compared directly crossbred cows to purebred cows. Therefore, our yearly estimates over 15 yr should be lower, especially due to the small differences on profit during the first 5 yr between pure breeding and crossbreeding schemes and due to the discounting rate applied in our study. Second, price context and farming systems were quite different. Indeed, we found profit improvement (here averaged over the whole simulation period) almost lower than those of these studies, which reported increases in profit up to $€ 297 /$ cow-year and up to $€ 90 /$ cow-year (by using a currency exchange rate of NZ $\$ 1$ to $€ 0.65$ and $\$ 1$ to $€ 0.89$ ), in Lopez-Villalobos et al. (2000) and Heins et al. (2012), respectively. In some cases, we found higher values than in Heins et al. (2012; improvement up to $€ 117 /$ cow-year), but never an increase as high than in Lopez-Villalobos et al. (2000) Nevertheless, profit improvement during yr 10 to 15 of simulation (this period being the most relevant to compare), was found to be the same magnitude or higher than in Heins et al. (2012), depending on the scenario (and using the currency exchange rates).

We performed a sensitivity analysis where contrasted values were given to milk price and concentrates price, which allowed us to assess a more unfavorable situation than the quite favorable 2014 French context (IDELE, 2016). Sensitivity on context of prices was not very pronounced and depended a little upon management objective (constant number of cows or constant volume of milk sold). Lower milk price and higher concentrate prices did not change or increased with limited magnitude the difference in profit in favor of crossbreeding. As concentrate price tended to increase during the past decade (European Commission - EU FADN, 2013) and will likely continue to do so (Godfray et al., 2010), whereas milk price might be more volatile with a trend to decrease, crossbreeding still appears a relevant option for Holstein operations.

Given our choice for initial herds and associated managerial conditions, external validity of our results should be examined critically. First, the results can be seen as also relevant for French dairy operations (or some European operations with close characteristics under similar economic contexts) other than those simulated here. Simulating a production level of 9,000 L of milk/ cow-year (i.e., greater than the current French average) allows us to state that conclusions in favor of crossbreeding are valid for operations with lower yield per cow because crossbred cows after F1 cows produce less than Holstein cows. Moreover, for such herds, expected improvement of profit will be larger. For herds with high-producing cows and good health and reproductive performance, crossbreeding might not increase profit. Second, for countries differing substantially from our assumptions, it is still valid to state that benefits from crossbreeding will remain nonsignificant or low until $5 \mathrm{yr}$, and that the lower the production levels are the more interesting crossbreeding will be. Connecting our results with, for example, those of Heins et al. (2012) suggests that, even if the magnitude of economic effects might be different in other countries, and thus further research is needed, crossbreeding would very likely be a relevant option, at least to consider for Holstein herds until 9,000 L/cow-year. For the initial herds we simulated, selection of sires was intended to minimize milk loss in production per cow with crossbreeding, which an important option; this was done by using sires with high 
merit for yield in all breeds. Using sires in all breeds with lower merit for yield in such herds would have led to lower milk production per crossbred cow and lower changes in profit, but crossbreeding will still be more favorable for profit than purebreeding. For other initial herds, for instance herds with lower milk yield and with an objective to improve milk solid contents or reproductive traits, selecting more balanced sires might provide an increase in profit of the same magnitude found here. However, the payment system for milk solids can be a critical issue because, depending on the country, as it can result in an incentive or a penalty to deliver more diluted or more concentrated milk.

From a practical perspective, our results highlight that, after starting crossbreeding, a farmer has to wait several years to perceive a sufficiently visible improvement of profit. Moreover, all the scenarios described here relied on a total shift toward $100 \%$ crossbreeding, when farmers frequently start with cross-mating just a part of their cow population. In such cases, the selected cows are often problem cows in France. Of course, implementing partial crossbreeding dilutes its benefits. All these reasons are plausible explanations for low adoption of crossbreeding, especially in France. We believe that studies including the transition phase and well adapted to the local context provide farm advisors with more efficient arguments to recommend crossbreeding where relevant.

\section{CONCLUSIONS}

With a simulation model, we quantified changes induced in Holstein operations by introducing crossbreeding with sires' selected for yield to provide answers about this long-term decision. In our results, crossbreeding schemes increased, more or less, net discounted profit over 15 yr in operations producing initially $9,000 \mathrm{~kg} /$ cow-year for different schemes, different management objectives, and different levels of prevalence of reproductive and health disorders. Improvement could reach up to €117/cow-year, especially under a high prevalence of disorders and an objective for a constant volume of milk sold. This improvement was similar or slightly higher when the operation had to face an unfavorable evolution of relative prices for milk and concentrates.

\section{ACKNOWLEDGMENTS}

This study was funded by PASS'SAS (Roulans, France). We acknowledge the numerous and relevant comments of the anonymous reviewers that helped us to improve this paper.

\section{REFERENCES}

Berry, D. P., E. Wall, and J. E. Pryce. 2014. Genetics and genomics of reproductive performance in dairy and beef cattle. Animal $8: 105-121$.

Buckley, F., N. Lopez-Villalobos, and B. J. Heins. 2014. Crossbreeding: Implications for dairy cow fertility and survival. Animal 8:122-133.

Coulon, J. B., L. Perochon, and F. Lescouret. 1995. Modelling the effect of the stage of pregnancy on dairy cows' milk yield. Anim. Sci. 60:401-408.

Cutullic, E., L. Delaby, Y. Gallard, and C. Disenhaus. 2011. Dairy cows' reproductive response to feeding level differs according to the reproductive stage and the breed. Animal 5:731-740.

de Haas, Y., H. W. Barkema, Y. H. Schukken, and R. F. Veerkamp. 2005. Associations between somatic cell count patterns and the incidence of clinical mastitis. Prev. Vet. Med. 67:55-68.

De Vries, A. 2006. Economic value of pregnancy in dairy cattle. J. Dairy Sci. 89:3876-3885.

Dechow, C. D., G. W. Rogers, J. B. Cooper, M. I. Phelps, and A. L. Mosholder. 2007. Milk, fat, prrotein, somatic cell score, and days open among Holstein, Brown Swiss, and their Crosses. J. Dairy Sci. 90:3542-3549.

Dezetter, C., H. Leclerc, S. Mattalia, A. Barbat, D. Boichard, and V. Ducrocq. 2015. Inbreeding and crossbreeding parameters for production and fertility traits in Holstein, Montbéliarde, and Normande cows. J. Dairy Sci. 98:4904-4913.

Dickerson, G. E. 1973. Inbreeding and heterosis in animals. J. Anim. Sci. 1973:54-77.

Djabri, B., N. Bareille, F. Beaudeau, and H. Seegers. 2002. Quarter milk somatic cell count in infected dairy cows: a meta-analysis. Vet. Res. 33:335-357

European Commission (EU FADN). 2013. EU dairy farms report 2013 Accessed Mar. 16, 2015. http://ec.europa.eu/agriculture/rica/ pdf/Dairy_Farms_report_2013_WEB.pdf.

Fourichon, C., H. Seegers, and F. Beaudeau. 2001. Health-control costs in dairy farming systems in western France. Livest. Prod. Sci. 68:141-156.

Godfray, H. C. J., J. R. Beddington, I. R. Crute, L. Haddad, D. Lawrence, J. F. Muir, J. Pretty, S. Robinson, S. M. Thomas, and C. Toulmin. 2010. Food security: The challenge of feeding 9 billion people. Science 327:812-818.

Grimard, B., S. Fréret, A. Chevallier, A. Pinto, C. Ponsart, and P. Humblot. 2006. Genetic and environmental factors influencing first service conception rate and late embryonic/foetal mortality in low fertility dairy herds. Anim. Reprod. Sci. 91:31-44.

Heins, B. J., L. B. Hansen, and A. De Vries. 2012. Survival, lifetime production, and profitability of Normande $\times$ Holstein, Montbéliarde $\times$ Holstein, and Scandinavian Red $\times$ Holstein crossbreds versus pure Holsteins. J. Dairy Sci. 95:1011-1021.

Heins, B. J., L. B. Hansen, and A. J. Seykora. 2006a. Fertility and survival of pure Holsteins versus crossbreds of Holstein with Normande, Montbeliarde, and Scandinavian Red. J. Dairy Sci. 89:4944-4951.

Heins, B. J., L. B. Hansen, and A. J. Seykora. 2006b. Production of pure Holsteins versus crossbreds of Holstein with Normande, Montbeliarde, and Scandinavian Red. J. Dairy Sci. 89:2799-2804.

Hortet, P., F. Beaudeau, H. Seegers, and C. Fourichon. 1999. Reduction in milk yield associated with somatic cell counts up to 600000 cells/ml in French Holstein cows without clinical mastitis. Livest. Prod. Sci. 61:33-42.

Hortet, P., and H. Seegers. 1998a. Calculated milk production losses associated with elevated somatic cell counts in dairy cows: Review and critical discussion. Vet. Res. 29:497-510.

Hortet, P., and H. Seegers. 1998b. Loss in milk yield and related composition changes resulting from clinical mastitis in dairy cows. Prev. Vet. Med. 37:1-20.

Humblot, P. 2001. Use of pregnancy specific proteins and progesterone assays to monitor pregnancy and determine the timing, frequencies and sources of embryonic mortality in ruminants. Theriogenology 56:1417-1433. 
Inchaisri, C., R. Jorritsma, P. L. A. M. Vos, G. C. van der Weijden, and H. Hogeveen. 2010. Economic consequences of reproductive performance in dairy cattle. Theriogenology $74: 835-846$.

Institut de l'Elevage (IDELE). 2016. Indice des prix d'achat des moyens de production agricole (IPAMPA). Accessed Jan. 15, 2016. http://idele.fr/services/outils/ipampa.html.

Jonhson, R., I. Omtvedt, and L. Walters. 1978. Comparison of productivity and performance for two-breed and three-breed crosses in swine. J. Anim. Sci. 46:69-82.

Jönsson, R. 2015. Estimation of heterosis and performance of crossbred Swedish dairy cows. Master thesis. Department of Animal Breeding and Genetics. Swedish University of Agricultural Sciences, Uppsala, Sweden.

Launay, A., and P. Le Mezec. 2013. Bilan D'indexation des Races Laitières, Résultats de la Campagne 2012. Institut de l'Elevage Collection Résultats, Paris, France.

Ledos, H., and S. Moureaux. 2013. Durée de gestation pour les principales races de l'espèces bovines, moyenne et variabilité. Institut de l'Elevage Collection Résultats, Paris, France.

Ledoux, D., J. L. Touze, C. Richard, A. A. Ponter, M. J. Bosc, and B. Grimard. 2011. Abnormal patterns of resumption of cyclicity after calving in Holstein cows: risk factors, relationships with the ultrasound appearance of the ovaries and with gestation failure after AI. Revue Méd. Vét. 162:98-106.

Lopez-Villalobos, N., D. J. Garrick, C. W. Holmes, H. T. Blair, and R. J. Spelman. 2000. Profitabilities of some mating systems for dairy herds in New Zealand. J. Dairy Sci. 83:144-153.

Lynch, M., and B. Walsh. 1998. Genetics and Analysis of Quantitative Traits. Vol. 1. Sinauer Associates, Sunderland, MA.

Pantoja, J. C. F., C. Hulland, and P. L. Ruegg. 2009. Dynamics of somatic cell counts and intramammary infections across the dry period. Prev. Vet. Med. 90:43-54.

Penasa, M., N. López-Villalobos, R. D. Evans, A. R. Cromie, R. Dal Zotto, and M. Cassandro. 2010. Crossbreeding effects on milk yield traits and calving interval in spring-calving dairy cows. J. Anim. Breed. Genet. 127:300-307.

Piccand, V., S. Meier, E. Cutullic, S. Weilenmann, P. Thomet, F. Schori, C. Burke, D. Weiss, J. R. Roche, and P. L. Kunz. 2011. Ovarian activity in Fleckvieh, Brown Swiss and two strains of Holstein-Friesian cows in pasture-based, seasonal calving dairy systems. J. Dairy Res. 78:464-470.

Poutous, M., M. Briend, S. Calomiti, D. Doan, C. Felgines, and G. Steier. 1981. Méthode de calcul des index laitiers. Bull. Tech. d'Information 361:433-446.
Robert-Briand, A. 2006. Infections intramammaires de la vache laitière en l'absence de traitement antibiotique systématique au tarissement. PhD Thesis. UMR 708 ENV Nantes and INRA gestion de la Santé Animale. University of Rennes, Rennes, France.

Robison, O. W., B. T. McDaniel, and E. J. Rincon. 1981. Estimation of direct and maternal additive and heterotic effects from crossbreeding experiments in animals. J. Anim. Sci. 52:44-50.

Rupp, R., and D. Boichard. 2003. Genetics of resistance to mastitis in dairy cattle. Vet. Res. 34:671-688.

Schepers, A. J., T. J. G. Lam, Y. H. Schukken, J. B. M. Wilmink, and W. J. A. Hanekamp. 1997. Estimation of variance components for somatic cell counts to determine thresholds for uninfected quarters. J. Dairy Sci. 80:1833-1840.

Schlecht, S., and A. Spiller. 2012. A latent class cluster analysis of farmers' attitudes towards contract design in the dairy industry. Agribusiness 28:121-134.

Sørensen, M. K., E. Norberg, J. Pedersen, and L. G. Christensen. 2008. Invited review: Crossbreeding in dairy cattle: A Danish perspective. J. Dairy Sci. 91:4116-4128.

Taylor, J. F., K. H. Taylor, and E. D. Decker. 2016. Holstein are the genomic selection poster cows. Proc. Natl. Acad. Sci. USA 113:7690-7692.

Uribe, H. A., B. W. Kennedy, S. W. Martin, and D. F. Kelton. 1995 Genetic parameters for common health disorders of Holstein cows. J. Dairy Sci. 78:421-430.

van Knegsel, A. T., S. G. van der Drift, J. Čermáková, and B. Kemp. 2013. Effects of shortening the dry period of dairy cows on milk production, energy balance, health, and fertility: A systematic review. Vet. J. 198:707-713

VanRaden, P. M. 2004. Invited review: Selection on net merit to improve lifetime profit. J. Dairy Sci. 87:3125-3131.

Veerkamp, R., P. Dillon, E. Kelly, A. Cromie, and A. Groen. 2002 Dairy cattle breeding objectives combining yield, survival and calving interval for pasture-based systems in Ireland under different milk quota scenarios. Livest. Prod. Sci. 76:137-151.

Walsh, S., F. Buckley, K. Pierce, N. Byrne, J. Patton, and P. Dillon. 2008. Effects of breed and feeding system on milk production body weight, body condition score, reproductive performance, and postpartum ovarian function. J. Dairy Sci. 91:4401-4413.

Wood, P. D. P. 1967. Algebraic model of the lactation curve in cattle Nature 216:164-165.

Zwald, N. R., K. A. Weigel, Y. M. Chang, R. D. Welper, and J. S. Clay. 2004. Genetic selection for health traits using producerrecorded data. I. Incidence rates, heritability estimates, and sire breeding values. J. Dairy Sci. 87:4287-4294.

\section{APPENDIX A}

\section{Modeling Reproductive Performance}

Consecutive reproductive states for heifers and cows are represented in Figure A1.

Probability of ovulation without associated estrus behavior $\left(\mathrm{P}_{\mathrm{EB}}\right)$ was modeled as a result of different factors:

$$
\mathrm{P}_{\mathrm{EB}}=\left(\mathrm{P}_{\mathrm{EBk}}+\mathrm{P}_{\mathrm{DMY}}\right),
$$

where $\mathrm{P}_{\mathrm{EBk}}=$ baseline probability of ovulation without associated estrus behavior depending on the genotype $\mathrm{k}$ of female (purebred or crossbred), the number of postpartum ovarian cycles and the number of postAI estrus; $\mathrm{P}_{\mathrm{DMY}}=$ additional probability of ovulation without estrus due to daily milk yield (DMY).
Decision to inseminate cows or heifers depended on the probability of estrus detection by the farmer. Cows producing more than $50 \mathrm{~L}$ a day were not bred. For cows, probability of fertilization $\left(\mathrm{P}_{\mathrm{FC}}\right)$ was modeled as a result of various multiplicative factors:

$$
\mathrm{P}_{\mathrm{FC}}=\mathrm{PA}_{\mathrm{CR}} \gamma_{\mathrm{SCA}} \gamma_{\mathrm{PR}} \gamma_{\mathrm{NC}} \gamma_{\mathrm{EC}} \gamma_{\mathrm{DIM}, \mathrm{DMY}}
$$

where $\mathrm{PA}_{\mathrm{CR}}=$ producing ability for conception rate; $\gamma_{\mathrm{SCA}}=$ change of scale coefficient (default value $=$ $1 / 65) ; \gamma_{\mathrm{PR}}=$ multiplicative factor for parity; $\gamma_{\mathrm{NC}}=$ multiplicative factor for number of previous estrus cycles; $\gamma_{\mathrm{EC}}=$ multiplicative factor for normality of the current estrus cycle; and $\gamma_{\text {DIM,DMY }}=$ multiplicative factor for the interaction between DIM and DMY. If, after 3 or 6 services, a cow was still not pregnant, the model added 


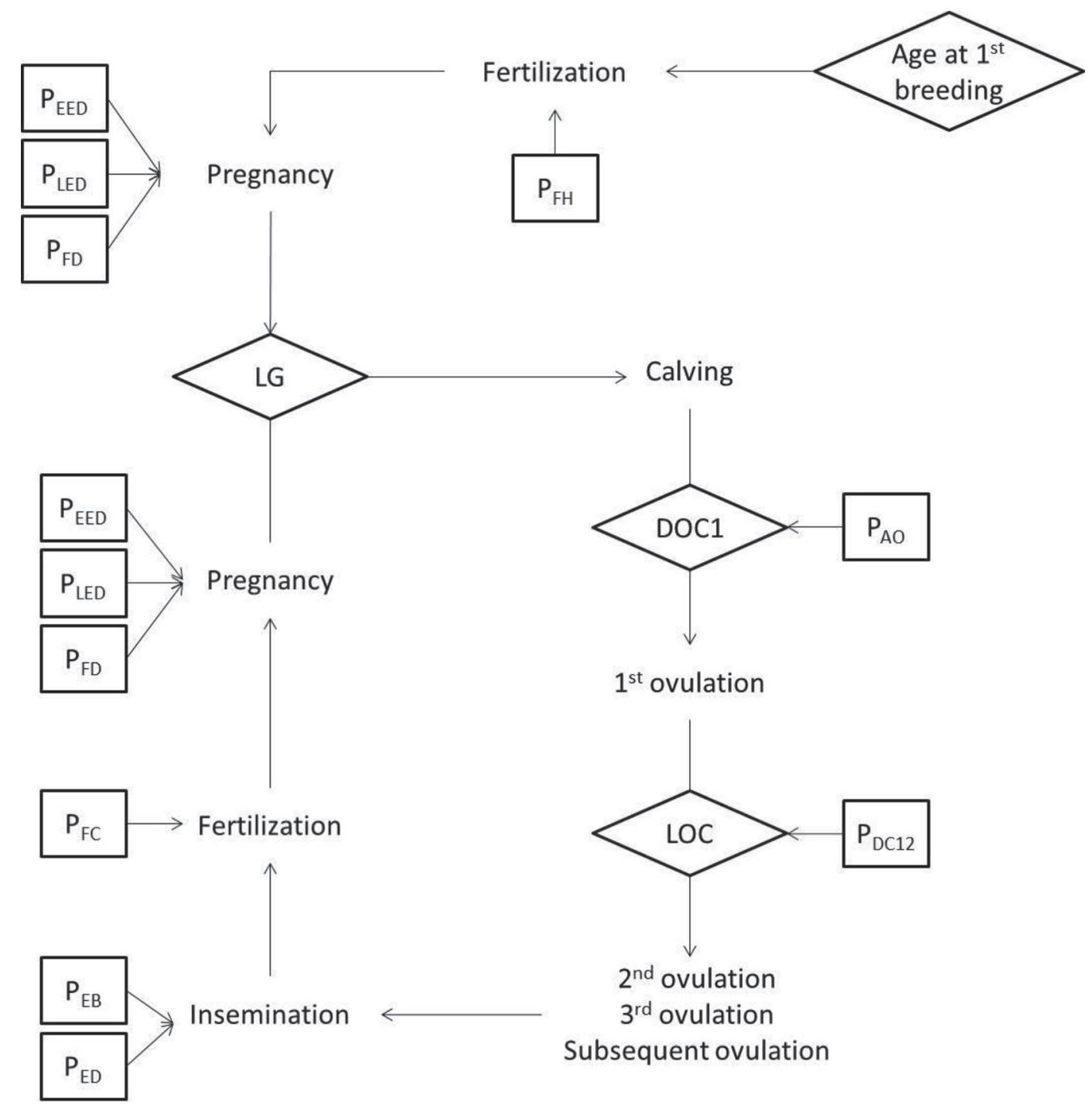

Figure A1. Diagram of the reproductive processes: consecutive states for heifers from first breeding to calving and for cows between 2 calvings. A diamond represents a length between 2 consecutive events. A box represents a probability of occurrence for normal or abnormal events occurring during a reproductive cycle. DOC1 = number of days from calving to first ovulation; LOC = length of ovarian cycle in days; LG = length of gestation; $\mathrm{P}_{\mathrm{AO}}=$ probability of anovulation after calving; $\mathrm{P}_{\mathrm{DC} 12}=$ probability of delayed first and second ovarian cycles; $\mathrm{P}_{\mathrm{EB}}=$ probability that a cow ovulates without associated estrus behavior; $\mathrm{P}_{\mathrm{ED}}=$ probability of estrus detection by the farmer; $\mathrm{P}_{\mathrm{CC}}=$ probability of conception for cows; $\mathrm{P}_{\mathrm{CH}}=$ probability of conception for heifers; $\mathrm{P}_{\mathrm{FED}}=$ probability of early embryonic death; $\mathrm{P}_{\mathrm{LED}}=$ probability of late embryonic death; $\mathrm{P}_{\mathrm{FD}}=$ probability of fetal death; $\mathrm{P}_{\mathrm{FC}}=$ probability of fertilization for cows; $\mathrm{P}_{\mathrm{FH}}=$ probability of fertilization for heifers .

1 treatment for infertility. This was just an economic calculation, and there was no effect on fertilization.

Heifers were not bred until the age of $540 \mathrm{~d}$. Hence, puberty was not modeled assuming that, at this age, all heifers had estrus cycles. When heifers were bred, the probability of fertilization $\left(\mathrm{P}_{\mathrm{FH}}\right)$ was calculated as

$$
\mathrm{P}_{\mathrm{FH}}=\mathrm{PA}_{\mathrm{CR}} \gamma_{\mathrm{SCA}} \gamma_{\mathrm{CRh}} \gamma_{\mathrm{NC}} \gamma_{\mathrm{EC}}
$$

where $\mathrm{PA}_{\mathrm{CR}}, \gamma_{\mathrm{SCA}}, \gamma_{\mathrm{NC}}$, and $\gamma_{\mathrm{EC}}$ are defined identical as for cows; $\gamma_{\mathrm{CRh}}=$ average conception rate for heifer in the herd (default value $=0.78)$.
For Holstein cows and heifers bred with Montbéliarde sires, the probability of fertilization was multiplied by 1.20 , which is the random effect of breed of sires estimated in the French genetic evaluations (A. Barbat, Institut National de la Recherche Agronomique, Jouy en Josas, France; personal communication). Parameters for modeling reproductive processes are given in Table A1. Figure A2 represents the probability of fertilization according to DIM and producing ability for milk yield for cows in parity 1 to 3 . 
Table A1. Definitions and values of model parameters for biological processes regarding reproduction ${ }^{1}$

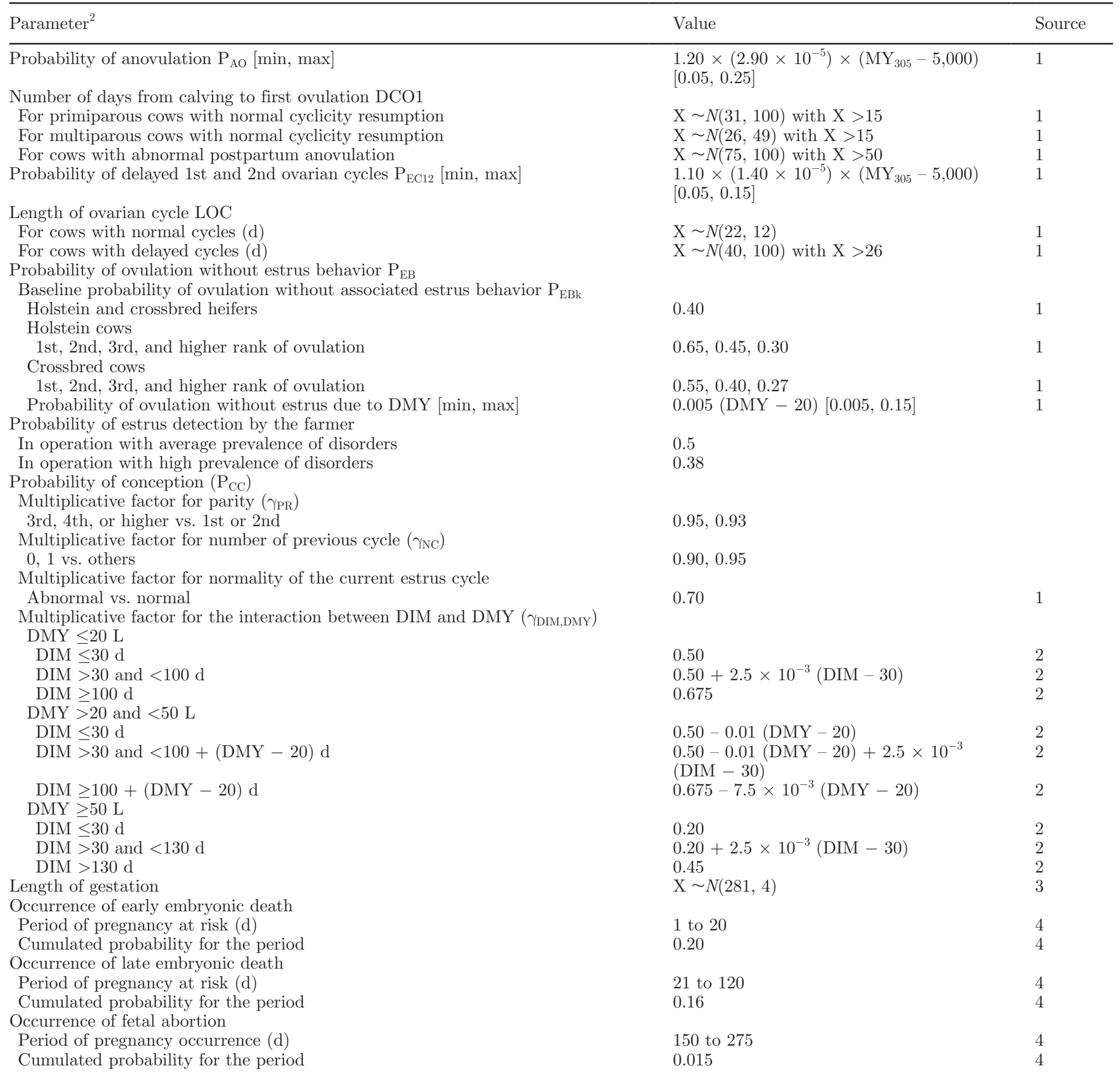

${ }^{1}$ All these parameters were computed from our expertise and the summarization of results found in 1: Cutullic et al. (2011), Ledoux et al. (2011), and Piccand et al. (2011); 2: Grimard et al. (2006); 3: Ledos and Moureaux (2013); 4: Humblot (2001) and Grimard et al. (2006). DMY = daily milk yield.

${ }^{2} \min =\operatorname{minimum} ; \max =\operatorname{maximum}$. 


\section{APPENDIX B}

\section{Simulation Processes for Occurrence of IMI}

In this model, occurrence of IMI for female i at day $\mathrm{t}$ was triggered with the probability $\left(\mathrm{p}_{\mathrm{IMI}_{\mathrm{it}}}\right)$ :

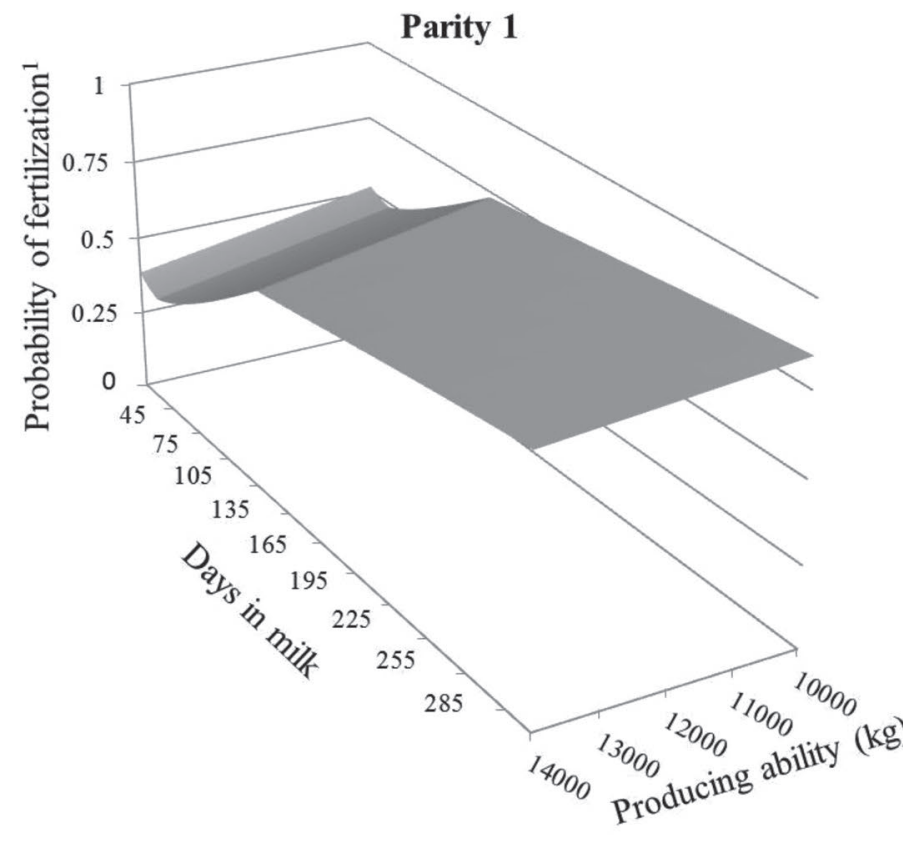

$$
\mathrm{p}_{\mathrm{IMI}}=\mathrm{PA}_{\mathrm{MAS}} \Psi_{\mathrm{SCA}} \Psi_{\mathrm{AID}} \Psi_{\mathrm{LS}_{\mathrm{it}}} \Psi_{\mathrm{PRi}_{\mathrm{i}}} \Psi_{\mathrm{PA}_{\mathrm{MY}}} \Psi_{\mathrm{MY}_{\mathrm{it}}} \Psi_{\mathrm{IMI}_{\mathrm{i}}} \Psi_{\mathrm{CO}_{\mathrm{t}}} \Psi_{\mathrm{HP}_{\mathrm{t}}}
$$

$[\mathrm{B} 1]$
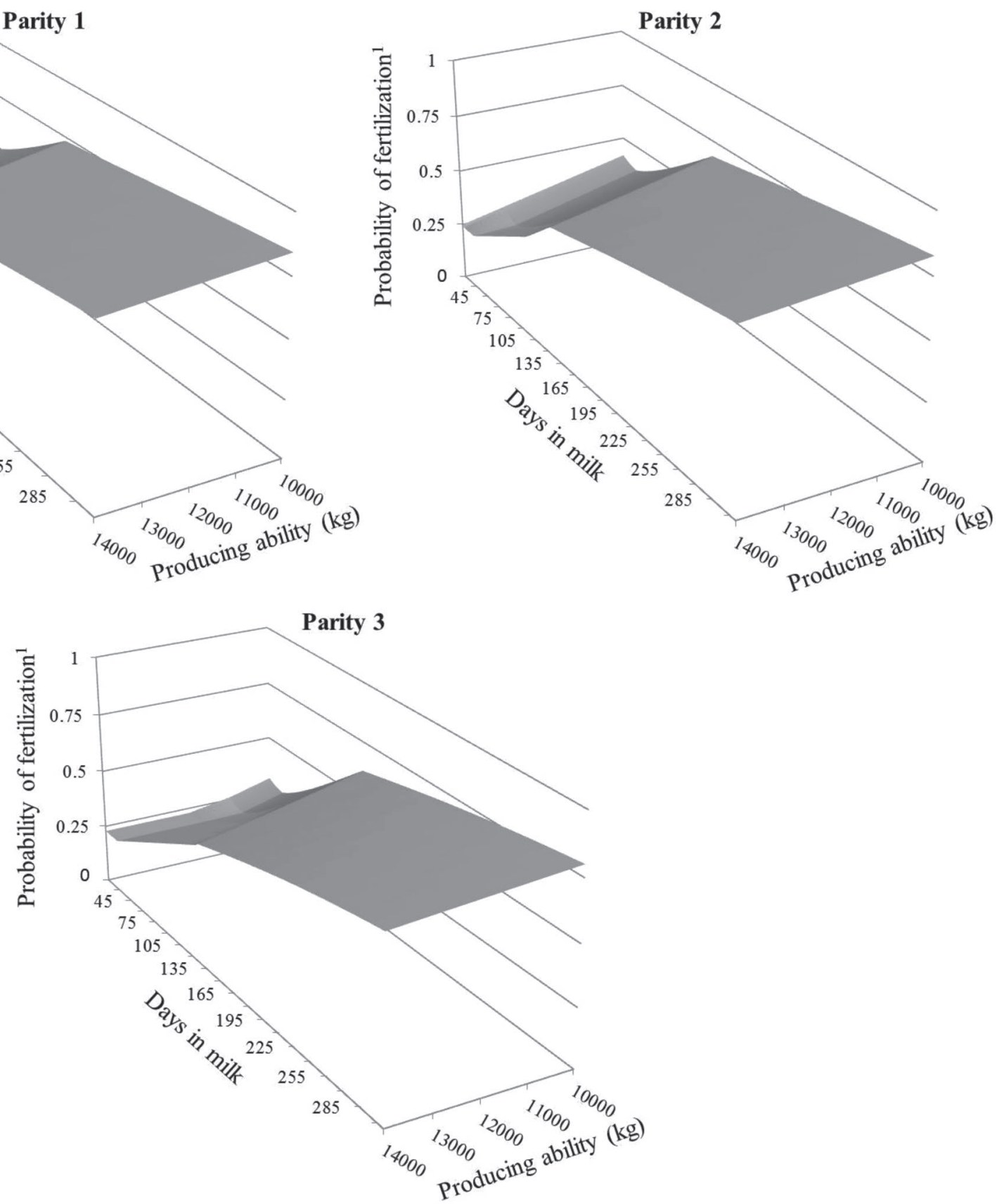

Figure A2. Probability of fertilization according to DIM and producing ability for milk yield for cows in parity 1 to 3 . Probability of fertilization does not take into account the producing ability of cows for fertilization and the effect of sire of bull (for Holstein cows bred with Montbéliarde sires) and assumes that the number of previous estrus cycles is superior to 1 and the current estrus cycle is normal. 
Table B1. Definitions and values of model parameters for processes regarding $\mathrm{IMI}^{1}$

\begin{tabular}{|c|c|c|}
\hline Parameter & Value & Source \\
\hline 45 DIM to drying off & 0.001 & Robert-Briand, 2006 \\
\hline 1 to $21 \mathrm{~d}$ after drying off & $0.014-5.6 \times 10^{-4} \mathrm{DDO}$ & Robert-Briand, 2006 \\
\hline 22 to 32 d after drying off & 0.002 & Robert-Briand, 2006 \\
\hline $7 \mathrm{~d}$ before to $1 \mathrm{~d}$ after calving & $-0.005+6.7 \times 10^{-3}(\mathrm{SG}-275)$ & Robert-Briand, 2006 \\
\hline Multiplicative factor for $\mathrm{PA}_{\mathrm{MY}}\left(\Psi_{\mathrm{PA}_{\mathrm{MY}}}\right)$ & $\begin{array}{l}0.8+0.2 \times 10^{-3}\left(\mathrm{PA}_{\mathrm{MY}}-4,000\right) \\
{[0.8,2.5]}\end{array}$ & Authors' expertise \\
\hline Multiplicative factor for $\mathrm{MY}_{\mathrm{t}}\left(\Psi_{\mathrm{MY}_{\mathrm{t}}}\right)$ & $0.5+0.05\left(\mathrm{MY}_{\mathrm{it}}-25\right) ;[0.5,1.8]$ & Authors' expertise \\
\hline Multiplicative factor for current or previous IMI in same cow $\left(\Psi_{\mathrm{IMI}_{1}}\right)$ & 3.20 & Robert-Briand, 2006 \\
\hline Multiplicative factor for contagion between cows $\left(\Psi_{\mathrm{CO}_{t}}\right)$ & $1+4 \mathrm{I}_{\mathrm{t}-1 \mathrm{t}-7}$ & Authors' expertise \\
\hline $250 \leq \mathrm{BMSCC} \leq 300$ & 0.36 & Authors' expertise \\
\hline $\mathrm{BMSCC}>300$ & 0.21 & Authors' expertise \\
\hline \multicolumn{3}{|l|}{ Operation with high prevalence of disorders } \\
\hline $\mathrm{BMSCC}<250$ & 0.89 & Authors' expertise \\
\hline $250 \leq \mathrm{BMSCC} \leq 350$ & 0.57 & Authors' expertise \\
\hline $\mathrm{BMSCC}>350$ & 0.21 & Authors' expertise \\
\hline Percentage of clinical cases $(\%)$ & 40 & Robert-Briand, 2006 \\
\hline Percentage of mild, moderate, severe cases (\% of clinical cases) & $50,40,10$ & Robert-Briand, 2006 \\
\hline Probability of culling for severe clinical cases & 0.02 & Authors' expertise \\
\hline Probability of death for severe clinical cases & 0.02 & Authors' expertise \\
\hline Probability of udder quarter loss for severe clinical cases & 0.02 & Authors' expertise \\
\hline \multicolumn{3}{|l|}{ Bacteriological cure } \\
\hline Multiplicative factor for spontaneous cure $\left(\phi_{\mathrm{SC}}\right)$ & 0.2 & Authors' expertise \\
\hline Multiplicative factor for effect of treatment $\left(\phi_{\mathrm{T}}\right)$ & 0.45 & Authors' expertise \\
\hline
\end{tabular}

${ }^{1} \mathrm{DDO}=$ days after drying off; $\mathrm{SG}=$ stage of gestation; $\mathrm{PA}_{\mathrm{MY}}=$ producing ability of female i for milk yield in kg; $\mathrm{MY}$ it $=$ daily milk yield in $\mathrm{kg} ; \mathrm{I}_{\mathrm{t}-1 \mathrm{t}-7}=$ incidence density in $\%$ (number of new case per number of cows in the herd between day t-7 to day t-1); BMSCC $=$ bulk milk SCC $(\times 1,000$ cells $/ \mathrm{mL})$.

where $\mathrm{PA}_{\mathrm{MAS}}=$ producing ability of female i for mastitis susceptibility; $\Psi_{\mathrm{SCA}}=$ change of scale coefficient (default value $=0.05) ; \Psi_{\mathrm{AID}}=$ annual incidence density of IMI cases (default value $=1.2$ ); $\Psi_{\mathrm{LS}_{\mathrm{it}}}=$ baseline risk according to lactation stage for female $\mathrm{i}$ at day t; $\Psi_{\mathrm{PRi}}$ $=$ multiplicative factor for parity of female $\mathrm{i} ; \Psi_{\mathrm{PA}_{\mathrm{MY}}}=$ multiplicative factor for producing ability for milk yield; $\Psi_{\mathrm{MY}_{\mathrm{it}}}=$ multiplicative factor for milk yield produced by female i at day t; $\Psi_{\mathrm{IMI}_{\mathrm{i}}}=$ multiplicative factor for current or previous IMI in female $\mathrm{i} ; \Psi_{\mathrm{CO}_{\mathrm{t}}}=$ multiplicative factor for contagion between cows at day t; $\Psi_{\mathrm{HP}_{\mathrm{t}}}$ $=$ multiplicative factor for herd level prevention applied at day t.

Severity of IMI was randomly triggered among 4 levels: subclinical, mild clinical, moderate clinical, and severe clinical cases. For severe clinical cases, probabili- ties of culling, mortality and loss of udder quarter were defined. Probability of bacteriological cure after the beginning of IMI at day $t\left(\mathrm{p}_{\mathrm{BC}_{\mathrm{t}}}\right)$ was calculated as

$$
\mathrm{p}_{\mathrm{BC}_{\mathrm{t}}}=\phi_{\mathrm{SC}} \phi_{\mathrm{T}}
$$

where $\phi_{\mathrm{SC}}=$ multiplicative factor for spontaneous cure of IMI; $\phi_{\mathrm{T}}=$ multiplicative factor for effect of treatment on IMI.

Parameters for IMI are given in Table B1 and were set up based on our expertise and the summarization of several publications, such as Schepers et al. (1997), Djabri et al. (2002), de Haas et al. (2005), and Pantoja et al. (2009). Figure B1 represents the probability of IMI occurrence according to DIM and producing ability for milk yield for cows in parity 1 to 3 . 


\section{APPENDIX C}

\section{Modeling Processes for Milk Yield and Solid Contents of Milk}

During lactation, daily milk yield, daily fat content, and daily protein content were calculated based partially on Wood (1967) and Coulon et al. (1995):

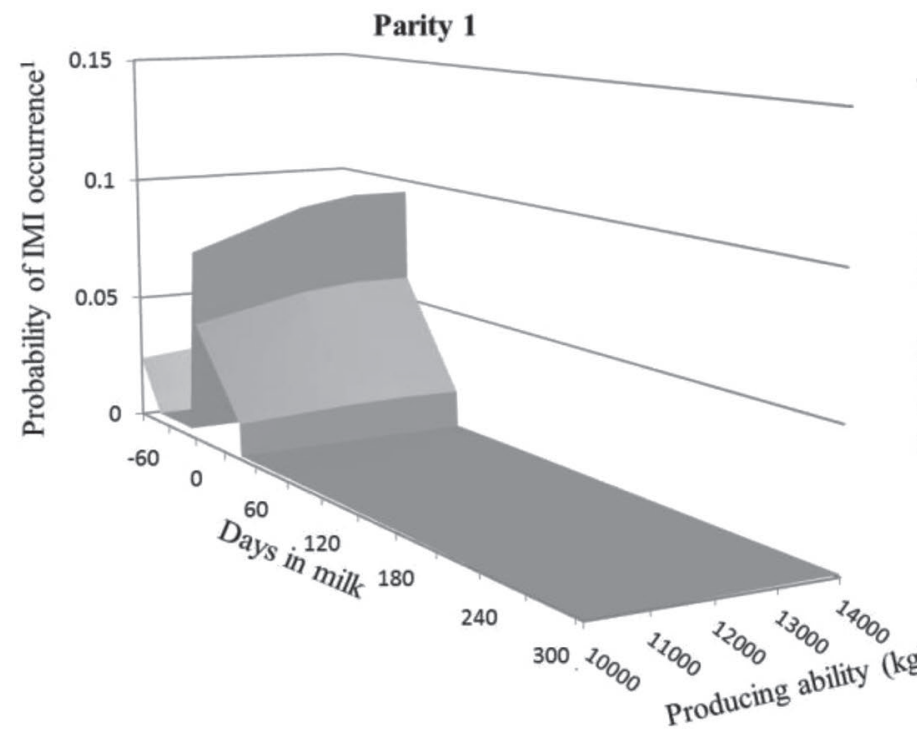

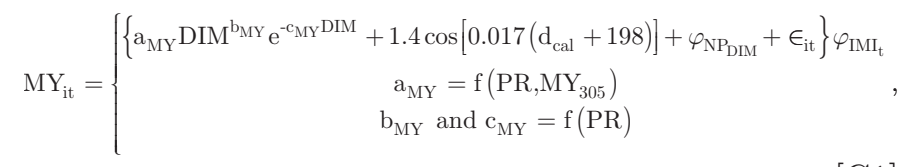

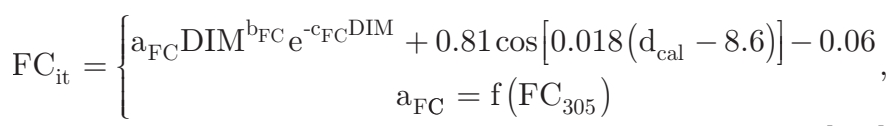

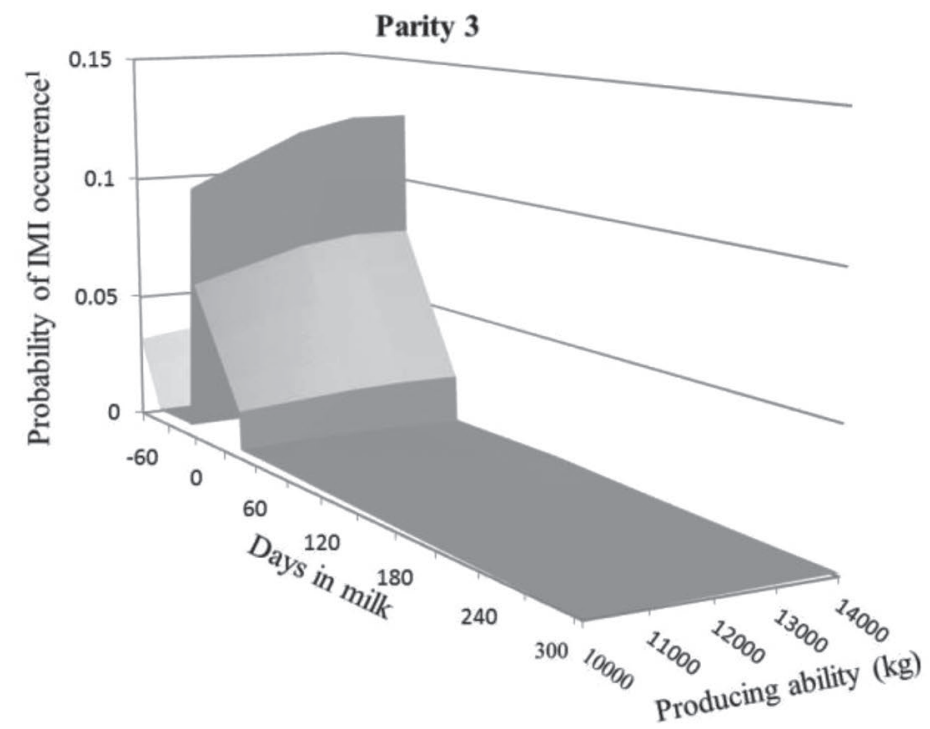

Figure B1. Probability of IMI occurrence according to DIM and producing ability for milk yield for cows in parity 1 to 3 . Probability of IMI occurrence does not take into account the producing ability of cows for mastitis susceptibility and the multiplicative factors for herd-level prevention, for current or previous IMI in the same cow and for contagion between cows. 
Table C1. Definitions and values of parameters for processes regarding daily milk yield and solid contents of milk

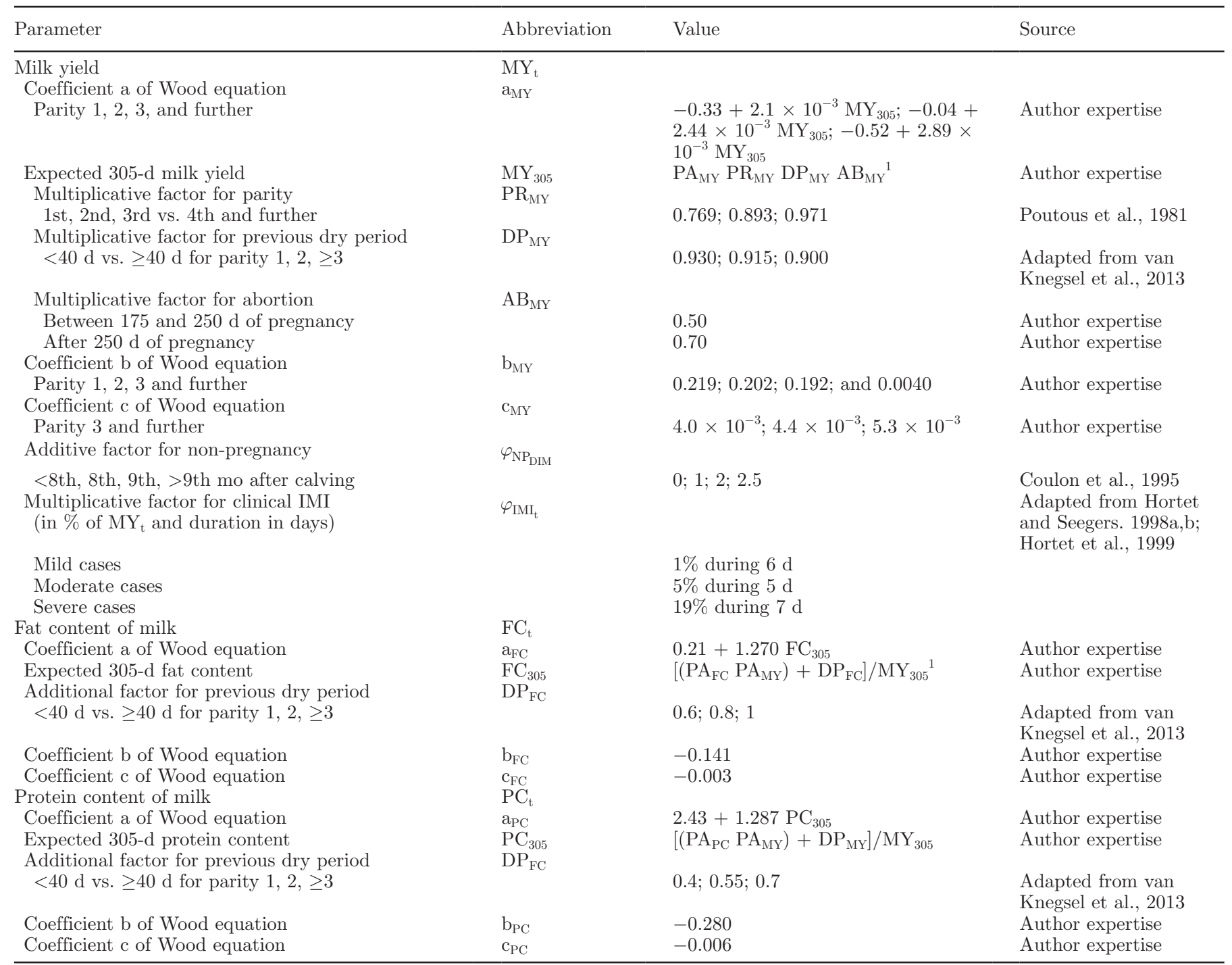

${ }^{1} \mathrm{PA}_{\mathrm{MY}}, \mathrm{PA}_{\mathrm{FC}}$, and $\mathrm{PA}_{\mathrm{PC}}=$ producing ability for milk yield, fat content, and protein content.

$\mathrm{PC}_{\mathrm{it}}=\left\{\begin{array}{c}\mathrm{a}_{\mathrm{PC}} \mathrm{DIM}^{\mathrm{b}_{\mathrm{PC}}} \mathrm{e}^{-\mathrm{C}_{\mathrm{PC}} \mathrm{DIM}}+1.48 \cos \left[0.017\left(\mathrm{~d}_{\text {cal }}-6\right)\right]+0.026 \\ \mathrm{a}_{\mathrm{PC}}=\mathrm{f}\left(\mathrm{PC}_{305}\right)\end{array}\right.$,

where $\mathrm{MY}_{\mathrm{it}}, \mathrm{FC}_{\mathrm{it}}$, and $\mathrm{PC}_{\mathrm{it}}=$ milk yield $(\mathrm{kg})$ and fat and protein contents $(\mathrm{g} / \mathrm{kg})$ of milk produced by female $i$ at day t; $a_{\mathrm{MY}}, \mathrm{a}_{\mathrm{FC}}, \mathrm{a}_{\mathrm{PC}}, \mathrm{b}_{\mathrm{MY}}, \mathrm{b}_{\mathrm{FC}}, \mathrm{b}_{\mathrm{PC}}, \mathrm{c}_{\mathrm{MY}}, \mathrm{c}_{\mathrm{FC}}$, and $\mathrm{c}_{\mathrm{PC}}$ $=$ coefficients of Wood equation for milk yield and fat and protein contents of milk; $\mathrm{d}_{\text {cal }}=$ calendar day; $\varphi_{\mathrm{NP}_{\mathrm{DIM}}}$ $=$ additive factor for nonpregnancy at DIM; $\epsilon_{\mathrm{it}}=$ ran- dom factor triggered from a normal distribution truncated in the interval $[-2,2]$ every day; $\varphi_{\mathrm{IMI}_{\mathrm{t}}}=$ multiplicative factor $(\leq 1)$ to account for clinical IMI effect on $\mathrm{MY}_{\mathrm{it}} ; \mathrm{PR}=$ parity of female $\mathrm{i} ; \mathrm{MY}_{305}, \mathrm{FC}_{305}$, and $\mathrm{PC}_{305}$ $=$ expected 305-d milk yield $(\mathrm{kg})$ and fat and protein contents $(\mathrm{g} / \mathrm{kg})$ of milk produced by female i. Parameters for multiplicative factors are given in Table C1. Figure C1 represents daily milk yield according to DIM and producing ability for milk yield for cows in parity 1 to 3 . 
Parity 1

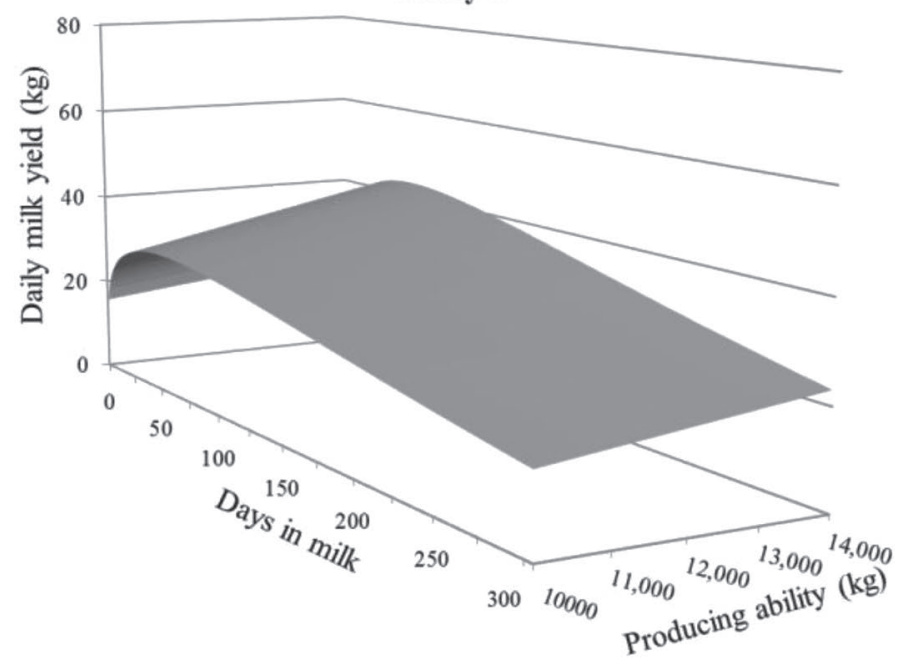

Parity 2

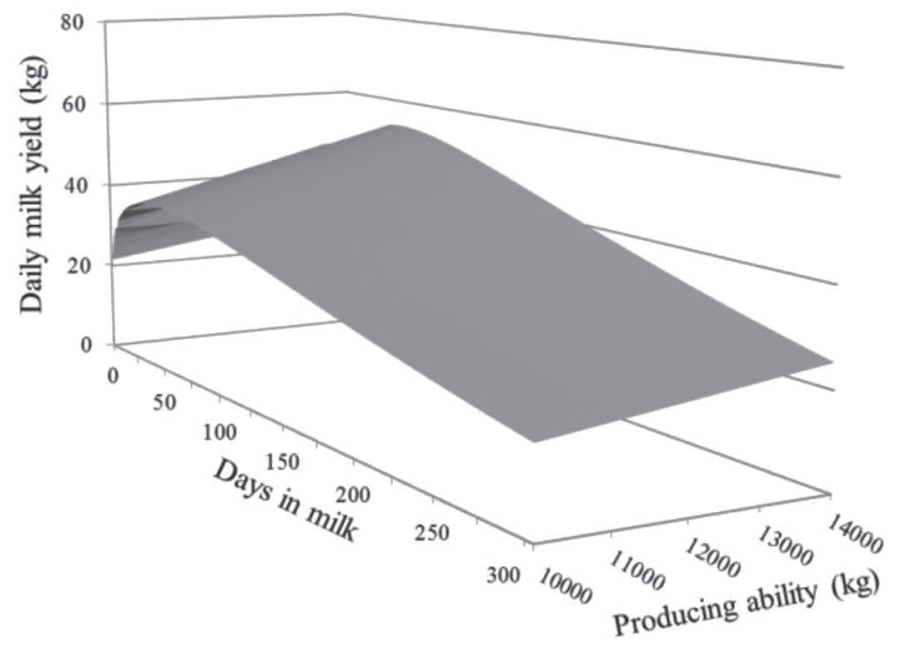

Parity 3

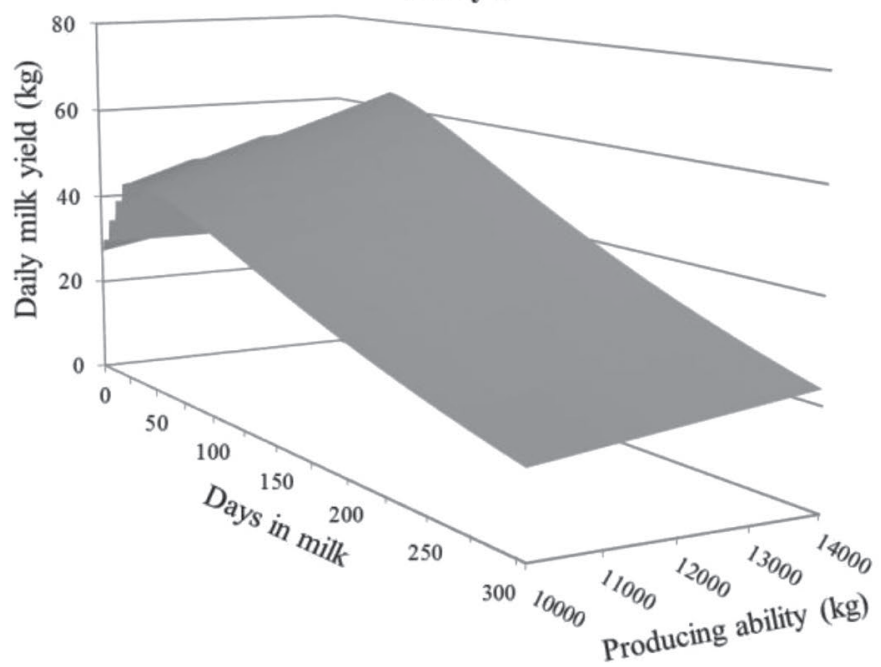

Figure C1. Daily milk yield according to DIM and producing ability for milk yield for cows in parity 1 to 3 . Daily milk yields were computed assuming that duration of dry period was normal (equal to $60 \mathrm{~d}$ ) and cows were pregnant at 8 mo after calving and did not abort. 


\section{APPENDIX D}

Table D1. Definitions and values of prices and costs parameters from French quotations in $2014^{1}$

\begin{tabular}{|c|c|}
\hline Parameter & Value \\
\hline \multicolumn{2}{|l|}{ Milk price $(€ / 1,000 \mathrm{~L})$} \\
\hline Reference January & 390 \\
\hline Reference February & 386 \\
\hline Reference March & 369 \\
\hline Reference April & 318 \\
\hline Reference May & 321 \\
\hline Reference June & 350 \\
\hline Reference July & 370 \\
\hline Reference August & 370 \\
\hline Reference September & 368 \\
\hline Reference October & 358 \\
\hline Reference November & 355 \\
\hline Reference December & 361 \\
\hline Penalty for bulk milk SCC over 250,000 cells $/ \mathrm{mL}$ & 3.05 \\
\hline Penalty for bulk milk SCC over 300,000 cells $/ \mathrm{mL}$ & 9.15 \\
\hline Penalty for bulk milk SCC over 400,000 cells $/ \mathrm{mL}$ & 18.29 \\
\hline Price bonus or depreciation per $\mathrm{kg} / 1,000 \mathrm{~L}$ of fat content referred to $38^{2}$ & 2.60 \\
\hline Price bonus or depreciation per $\mathrm{kg} / 1,000 \mathrm{~L}$ of protein content referred to $32^{2}$ & 6.60 \\
\hline \multicolumn{2}{|l|}{ Animal sale prices $(€)$} \\
\hline Holstein male calf sold at $2 \mathrm{wk}$ & 80 \\
\hline Crossbred male calf sold at $2 \mathrm{wk}$ & 110 \\
\hline Holstein female calf sold at $2 \mathrm{wk}$ & 40 \\
\hline Crossbred female calf sold at 2 wk & 60 \\
\hline Holstein heifer culled after 3 unsuccessful AI & 800 \\
\hline Crossbred heifer culled unsuccessful AI & 1,000 \\
\hline Live heifer sold $\geq 6$ mo after conception & 1,200 \\
\hline Holstein cow culled & 1,000 \\
\hline Crossbred cow culled & 1,200 \\
\hline \multicolumn{2}{|l|}{ Concentrates costs $(€ / t)$} \\
\hline Concentrates provided to all cows & 265 \\
\hline Supplementation concentrates provided to produce over $30 \mathrm{~L} / \mathrm{d}$ & 340 \\
\hline Concentrates distributed to heifers & 200 \\
\hline \multicolumn{2}{|l|}{ Reproductive costs ( $€$ /occurrence) } \\
\hline AI & 28 \\
\hline Infertility treatment & 25 \\
\hline \multicolumn{2}{|l|}{ Udder health $\operatorname{costs}^{3}(€ /$ cow $)$} \\
\hline Clinical mastitis treatment & 22 \\
\hline Low level of prevention & 15 \\
\hline Intermediate level of prevention & 27 \\
\hline High level of prevention & 40 \\
\hline \multicolumn{2}{|l|}{ Veterinary cost other than for udder health and reproductive control } \\
\hline Health disorders treatment $(€ /$ occurrence $)$ & 110 \\
\hline Lump sum for living cows $(€ /$ cow-year $)$ & 12 \\
\hline Lump sum if culling or death of a cow $(€ /$ animal $)$ & 50 \\
\hline \multicolumn{2}{|l|}{ Other undifferentiated variable costs (lump sums, $€$ /animal) } \\
\hline Male calf alive at $2 \mathrm{wk}$ & 20 \\
\hline Male or female calf dead at $2 \mathrm{wk}$ & 10 \\
\hline Female calf alive at $2 \mathrm{wk}$ & 25 \\
\hline Heifer-year $0-1$ yr old & 23 \\
\hline Heifer-period 1-2 yr old (period from May to October) & 25 \\
\hline Heifer-period 1-2 yr old (period from November to April) & 35 \\
\hline Heifer-period $>2$ yr old (period from May to October) & 35 \\
\hline Heifer-period $>2$ yr old (period from November to April) & 45 \\
\hline Cow-year & 55 \\
\hline
\end{tabular}

${ }^{1}$ Source for milk price was http://www.web-agri.fr/observatoire_marches/lait.html, accessed Mar. 5, 2014; source for animal sale prices and concentrate costs was La France Agricole, March 2014, pages 80-81.

${ }^{2}$ Milk price adjustment in $€ / 1,000 \mathrm{~L}$ for $1 \mathrm{~kg} / 1,000 \mathrm{~L}$ increase or decrease in fat or protein contents, respectively, to $38 \mathrm{~kg} / 1,000 \mathrm{~L}$ and $32 \mathrm{~kg} / 1,000 \mathrm{~L}$.

${ }^{3}$ Levels of udder health prevention depend on bulk milk SCC threshold. 